\title{
Turbidity retrieval and monitoring of Danube Delta waters using multi- sensor optical remote sensing data: An integrated view from the delta plain lakes to the western-northwestern Black Sea coastal zone
}

\author{
Fabio N. Güttler ${ }^{a, *}$, Simona Niculescu ${ }^{a}$, Francis Gohin $^{\mathrm{b}}$
}

\author{
a LETG-Brest, Géomer, UMR 6554 CNRS, European Institute for Marine Studies, 29280 Plouzane, Brittany, \\ France \\ b IFREMER/DYNECO/PELAGOS, Centre Ifremer de Brest, BP 70, 29280 Plouzane, Brittany, France \\ *: Corresponding author : Fabio N. Güttler, tel.: + 33298498691 ; email addresses : guttler@univ-brest.fr ; \\ fabioguttler@gmail.com
}

\begin{abstract}
:
Based on multi-sensor optical remote sensing techniques, more than 80 medium and high spatial resolution satellite images were used for studying the turbidity patterns of Danube Delta waters. During a selected 4-year temporal coverage (2006 to 2009), the turbidity gradients were simultaneously analyzed in the delta plain lakes and in the Black Sea western-northwestern coastal zone. Two distinct, but complementary, methodologies for retrieving turbidity were employed, one for the lakes and the other for the coastal zone. After comparing the turbidity satellite-derived turbidity products with in-situ measurements, the inter-comparability of the products was independently verified. Then, through an integrative analysis, the initial hypothesis of turbidity control by the Danube River inputs was tested in both areas (Delta plain and coastal zone). Seasonal turbidity patterns were identified together with the mechanisms responsible for its important temporal and spatial variability. Reciprocal contributions derived from the association of multi-scale satellite products were highlighted.
\end{abstract}

\section{Highlights}

Turbidity retrieval at different spatial scales from multi-sensor algorithms Integrated analysis of turbidity from Danube Delta plain lakes to coastal zone Identification of seasonal turbidity patterns and principal controlling mechanisms Description of spatial and temporal variability detected within the study area

Keywords: Turbidity ; Satellite remote sensing ; Danube Delta ; Delta plain lakes ; Westernnorthwestern Black Sea ; Danube River plume ; Phytoplankton ; Macrophytes 


\section{Introduction}

Large amounts of suspended particulate matter (SPM) exported by turbid rivers directly affect phytoplankton productivity, nutrient dynamics and the transport of pollutants in coastal zones (Doxaran et al., 2009). However, spatial and temporal dynamics of turbid waters flowing out of big river mouths are not usually well known.

The Danube River and its contributors cross nineteen European countries before reaching the West coast of the Black Sea. The Black Sea is a semi-enclosed sea presenting a widespread abyssal plain with depths between 2000 and $2200 \mathrm{~m}$. Its western and, especially, northwestern sections are particularly shallow. From Odessa (Ukraine) until Mangalia (south Romania) the coastal slope is low, creating an extensive area less than $200 \mathrm{~m}$ deep up to 150-200 km from the shoreline.

In the context of the Black Sea drainage basin, the Danube River is the most important source of liquid and solid discharges (Ludwig et al., 2009 and Mikhailov and Mikhailova, 2008). The liquid contribution is of about $205 \mathrm{~km}^{3}$ year $^{-1}$ (59\% of the total water runoff flowing to the Black Sea) whereas the SPM contribution ranges between 36.3 and 52.4 million tons per year (about $48 \%$ of the total SPM load reaching the Black Sea). Danube turbid fresh waters are constantly mixed with the Black Sea brackish waters (salinity of about 17-18 PSU) in the western-northwestern shallow area. Since tidal variation is 
small, between 7 and $12 \mathrm{~cm}$ (Giosan 2007), the active water mixing and circulation are carried out mostly by winds.

Furthermore, the fluvial-marine contact zone is quite large because Danube splits up itself into multiple distributaries across a wide deltaic plain $\left(4,142 \mathrm{~km}^{2}\right)$ shared among Romania and Ukraine. Vast areas of compact reedbeds usually surround the three hundred freshwater lakes of the delta. Many of these shallow lakes are connected to channels or canals providing turbid water from the Danube, while others depend on flood events to be supplied by the turbid waters coming from the river. Additionally, there are a few lakes almost isolated of this general water circulation. Important seasonal growth of floating and submerged macrophytes also occurs in the majority of the lakes.

Analyzing turbidity patterns in complex environments, like Danube Delta and its coastal zone, requires non-traditional approaches. Remote sensing multi-sensor techniques offer reliable advantages to observe and understand intricate processes operating on different space-time scales and especially in large areas with difficult and sometimes restricted access (e.g. Biosphere Reserve core areas).

Turbidity is an important water quality parameter and an indicator of water pollution (Anderson 2005; Petus et al. 2010). The ecological importance of turbidity is mainly related to light limitation for phytoplankton growth and can be also used as an eutrophication indicator. Solid loads may either be roughly estimated from turbidity measurements in the cases where the biologic fraction is small or can be properly subtracted. Turbidity gradients provide also relevant elements for identifying and interpreting geomorphologic and hydrological processes, as sediment transport, deposition and resuspension. By identifying the sources and the spatial distribution of suspended matters it is possible to deduce relevant spatial information about the nutrient availability, which will have great importance on primary production of coastal waters.

The turbidity concept is associated with the "cloudiness" of water (Davies-Colley and Smith 2001) which is caused by the presence of suspended and dissolved matter, such as clay, silt, finely divided organic matter, plankton and other microscopic organisms, organic acids, and dyes (ASTMInternational 2003). In other words, turbidity is an expression of the optical properties of a liquid that causes light rays to be scattered and absorbed rather than transmitted in straight lines through a sample (ASTM-International 2003). Turbidity is always a relative measurement, comparing the amount of light scattered by a sample with the amount scattered by a standard. The more light that is deflected the higher the turbidity of the sample (NWEA 2000).

This study aims to analyze the turbidity patterns of Danube delta waters simultaneously in the delta plain lakes and in the Black Sea western-northwestern coastal zone by using remote-sensing images obtained from different sensors.

\section{Data and methods}

\subsection{Study area}

The study area starts at the Danube Delta apex, characterized by the first division of Danube River in the upper portion of the delta plain, and widens until about $150 \mathrm{~km}$ eastwards from the Delta shoreline, in the Black Sea (fig. 1). It can be dissociated on two sub areas: A - The Danube Delta plain (containing lakes, rivers branches and channels) and B - The Danube Delta coastal zone (westernnorthwestern Black Sea). 


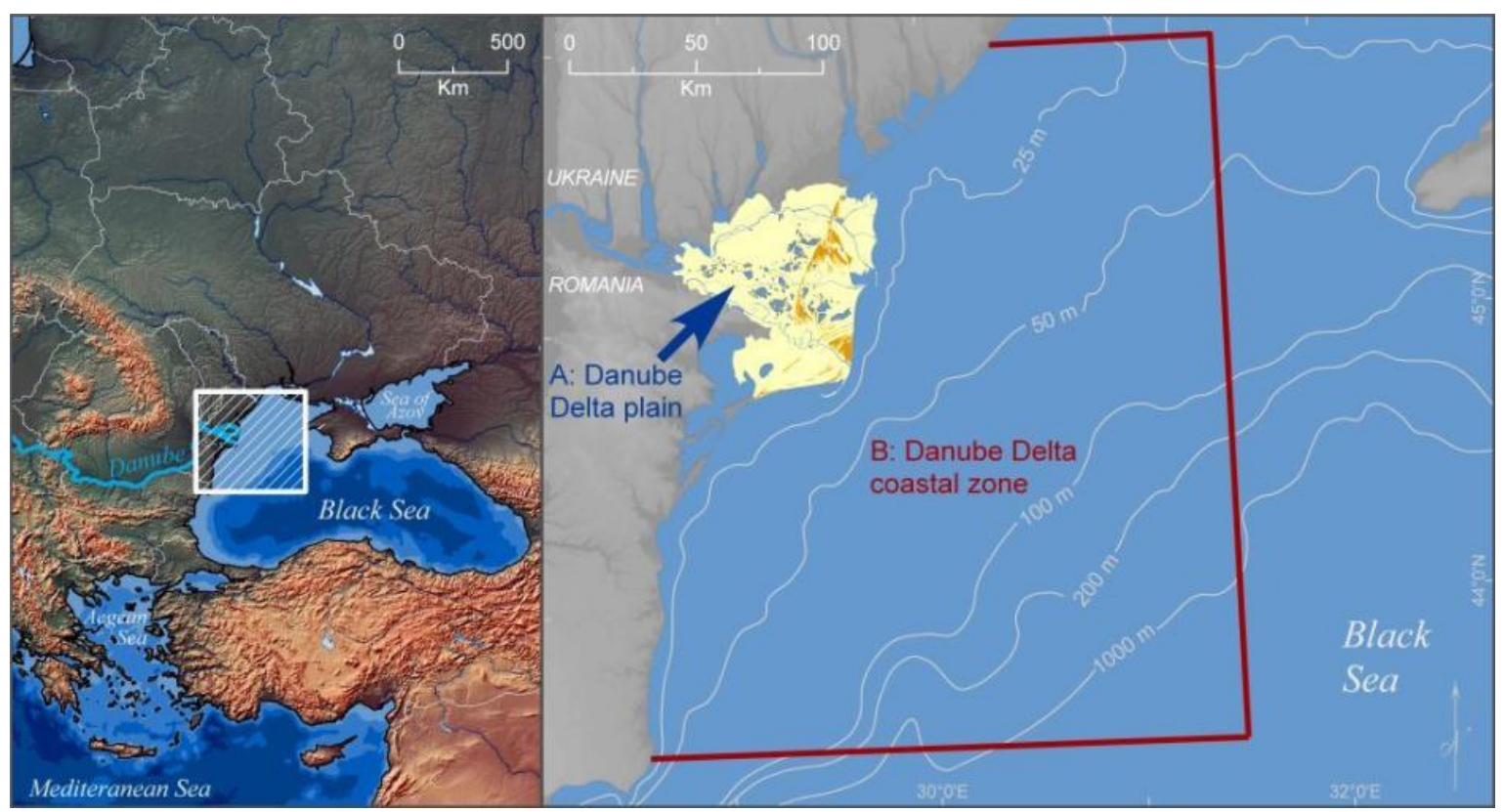

Fig. 1. Geographical localization of Danube Delta and western-northwestern Black Sea. Spatial delimitation of study zone and sub areas (A and $B$ ) is indicated on the map.

The Danube Delta presents a complex hydrological system which has been greatly modified since the first navigation works in the nineteenth century. Even though, the Danube Delta maintained its prominent biodiversity in a better state than most other deltas in Europe (Gâştescu and Stiuca 2008; Tudorancea and Tudorancea 2006). Since the beginning of the nineties, the Danube Delta became a Biosphere Reserve (MAB-UNESCO), a RAMSAR site and was included on the list of the World Natural Heritage (UNESCO).

The Danube Delta is a flat zone with an average altitude of about $0.52 \mathrm{~m}$ above the Black Sea mean level, while approximately 93\% of its territory is under $2 \mathrm{~m}$ (Bondar and Panin 2001; Driga 2004; Gâştescu and Stiuca 2008). The Danube Delta plain is crossed by three main river distributaries, called branches (or arms): Chilia in the North, Sulina in the center and Sfântu Gheorghe in the South (fig. 2). A juxtaposition of numerous ancient beach ridges, roughly oriented $\mathrm{N}-\mathrm{S}$, divide also the plain on a "fluvial delta plain" (west) and a "fluvio-marine delta plain" (east). Between the branches, sets of lakes fill the depression areas, structuring hydrographic sub-units, also called hydrographic complexes (Bondar and Panin 2001; Oosterberg et al. 2000). About three hundred freshwater lakes are present inside the four principal hydrologic sub-units: Şontea-Furtuna, Matiţa-Merhei, Gorgova-Uzlina and Roşu-Puiu (fig. 2). 


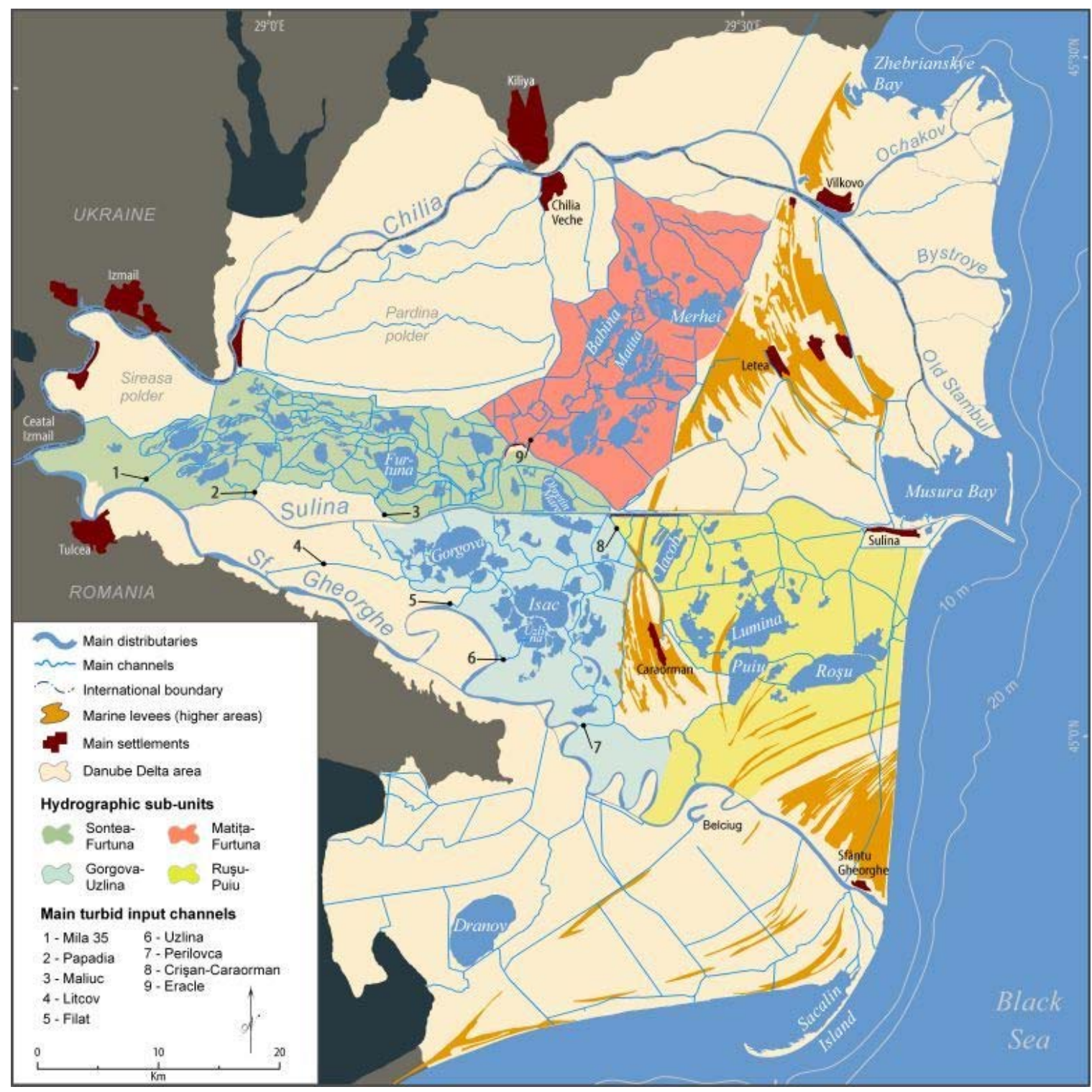

Fig. 2. Hydrologic sub-units and overview of the Danube Delta plain. Hydrographic sub-units boundaries were redrawn from Oosterberg et al. 2000.

The lakes are shallow within the entire delta (average depth 1.7-3.9 m) and vary greatly in size (0.7$43 \mathrm{~km}^{2}$ ), even though they are usually larger and deeper in the fluvio-marine part (Roşu-Puiu sub-unit) of the delta (Coops et al. 2008). From the river branches, some channels (natural and artificial) are permanently allowing water and sediment inflow into the hydrographic sub-units. Inside each hydrographic sub-unit, secondary channels ensure the connections with the lakes. Nevertheless, lakes in a same hydrographic depression are frequently separated only by extents of compact reedbeds (sometimes even by floating reedbeds called "plaur"). Thus, slow water flow "lake-to-lake" through and bellow reed vegetation also occurs.

According to field observations, satellite image interpretation and also specific literature (Bondar and Panin 2001; Driga 2004), the flow direction of some principal channels (e.g. Perilovca channel - fig.2) connecting the river to lakes can change in function of water level variations in the delta plain, although not common. Some of the main mouths derived from the Danube are in Ukraine (North sector) and some are in Romania (Central and South sectors). From the Chilia branch, which retains about $55 \%$ of Danube liquid discharge, five principal mouths are formed downstream of Vilkovo city, where starts the secondary delta of Chilia. The Sulina branch, which retains about $22 \%$ of Danube discharge, is the 
most transformed branch of the delta. At Sulina's mouth, two parallel piers (jetty system) of about $9 \mathrm{~km}$ length were built to allow the navigation of maritime ships. The southern branch, called Sf. Gheorghe, keeps about $23 \%$ of Danube discharge and possesses also a secondary delta. This secondary delta, much smaller than the Chilia one, is growing and consequently filling up the elongated bay situated behind the spit called "Sacalin Island".

\subsection{Satellite data and in-situ measurements}

In order to define the optimal temporal coverage of the satellite data sets, a daily water level time series (starting from 1932 up to 2010) was analyzed. Water level measurements were recorded at the Tulcea station, located near to the entry of the Danube Delta (fig. 2). The main objective was to recognize relevant periods of low and high water levels on Danube Delta and in particular to choose the most appropriate time intervals for acquiring satellite data. Daily liquid discharge data from Ceatal Izmail station (placed at the Delta apex) was also examined and compared to the river water level from Tulcea for the period 1932-2008. Since the two time series showed a very high correlation $\left(R^{2}=0.97\right)$ Bondar and Panin (2001) already noticed this behavior from a previous period - only water level values are presented in this article.

Important inter and intra-annual water level variations can be observed by analyzing historical water levels and river discharge measurements. The seasonal variability is characterized by a maximum in April through June and a minimum in September through November. Four years were selected to compose the remote sensing data set (fig. 3): 2006, an unlike year with high water levels and huge inundations in the delta plain; 2007, another unlike year with very low water levels and without significant inundations; 2008, a "typical" year with the water levels very close to the historical average; 2009, an year also close to the historical average except for one fast "inundation peak" registered during the summer.

Within the selected 4-year temporal coverage, 84 satellite images were analyzed. From this total, 52 images were issued from the MERIS optical sensor (Envisat) at full resolution (300m) and 32 from multisource high resolution optical sensors (considered here as encompassing spatial resolutions from 10 to $30 \mathrm{~m}$ ): AVNIR-2 (ALOS), HRVIR (SPOT-4), TM (Landsat-5) and ETM+ (Landsat-7). The temporal distribution of the entire satellite data set, superposed to local water levels (Tulcea station), is showed on figure 3. Two additional Landsat-5 TM images from June 2010 were used for assessment and validation purposes. Some historical Landsat MSS images, from the seventies and eighties, were also used for long term comparative analysis. Table 1 presents the most important technical characteristics of the optical sensors used in this research. 

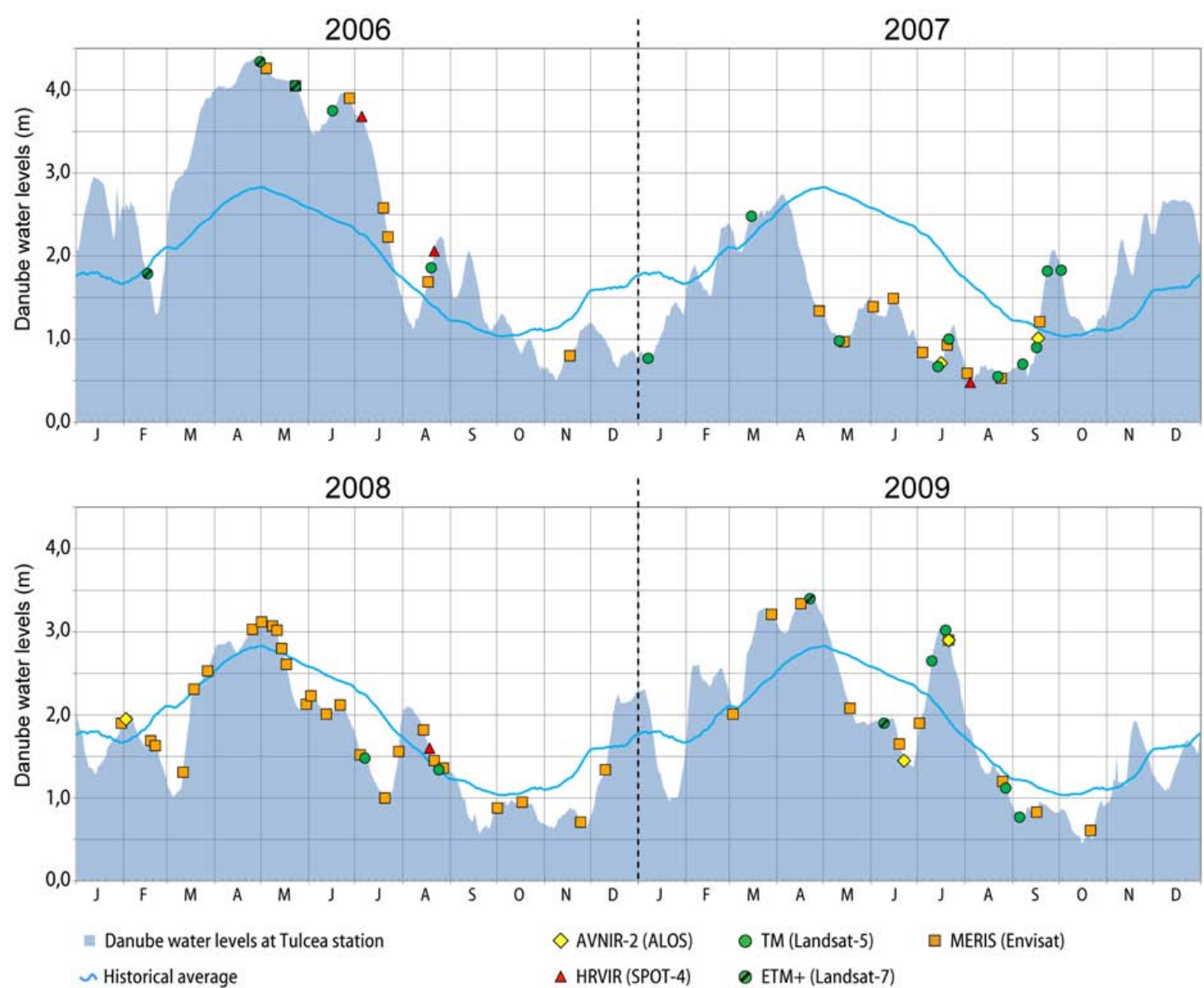

Fig. 3. Water levels at Tulcea station from 2006 until 2009 and the respective satellite data temporal coverage.

Table 1. Most important technical characteristics of the selected optical sensors related to their satellite images.

\begin{tabular}{|l|l|l|l|}
\hline Sensor & $\begin{array}{l}\text { Spatial } \\
\text { resolution }\end{array}$ & $\begin{array}{l}\text { Spectral resolution (Visible and NIR } \\
\text { regions) }\end{array}$ & Scene size \\
\hline MERIS* (Envisat) & $300 \times 300 \mathrm{~m}$ & 15 bands ; bandwidth range 3,75 - 10 nm & $575 \times 575 \mathrm{~km}$ \\
\hline TM (Landsat-5) & $30 \times 30 \mathrm{~m}$ & 4 bands ; bandwidth range $70-140 \mathrm{~nm}$ & $170 \times 185 \mathrm{~km}$ \\
\hline ETM+ (Landsat-7) & $30 \times 30 \mathrm{~m}$ & 4 bands ; bandwidth range $70-140 \mathrm{~nm}$ & $170 \times 183 \mathrm{~km}$ \\
\hline HRVIR (SPOT-4) & $20 \times 20 \mathrm{~m}$ & 3 bands ; bandwidth range $70-110 \mathrm{~nm}$ & $60 \times 60 \mathrm{~km}$ \\
\hline AVNIR-2 (ALOS) & $10 \times 10 \mathrm{~m}$ & 4 bands ; bandwidth range $80-130 \mathrm{~nm}$ & $70 \times 70 \mathrm{~km}$ \\
\hline
\end{tabular}

* Full resolution mode

Water transparency in-situ observations were realized using a Secchi disk. For the delta plain area, Secchi depth observations were realized over 18 lakes during the two first weeks of June 2010. For the Black Sea coastal zone, Secchi depth acquisitions were performed by the National Institute for Marine Research and Development "Grigore Antipa" during cruises realized in 2007, 2008 and 2009 (during Spring, Summer and Autumn). 
River SPM ( $\mathrm{mg} \mathrm{I}^{-1}$ ) data was acquired approximately monthly (from 1997 until 2008) in the context of the ICPDR (International Commission for the Protection of the Danube River) monitoring program. We used SPM data provided by three ICPDR stations located inside Danube Delta, at the distal part of the three main river branches (fig.2): Chilia (Vilkovo Station, about $1 \mathrm{~km}$ upstream Vilkovo city), Sulina (Sulina Station, about $10 \mathrm{~km}$ upstream Sulina city) and Sf. Gheorhe (Sf. Gheorghe Station, few hundred meters downstream Sf. Gheorghe village).

Complementary wind speed/direction data, from the GFS-NOAA model and from the Wunderground international network stations (Sulina location), were also used for a better understanding of the turbidity variations along the period analyzed 2006-2009. The spatial resolution of the GFS-NOAA model is of 0.5 degree and the time step considered for wind data analysis was of 6 hours. Sulina station data provided by Wundergroung international network presents also a 6 hours time step.

\subsection{Turbidity, SPM and Secchi depth measurements}

Turbidity, SPM and Secchi depth are three variables of the environment tightly related. The SPM may come from mineral, algal particles, biogenic debris or aggregates (flocs). In the Danube coastal areas, as generally on the continental shelf, SPM is mainly of mineral origin (resuspension or sediment in plumes). The contribution of phytoplankton is lower. Gohin (2011) proposes the following equation to relate turbidity to non_algal and Chlorophyll-derived SPM, whatever the origin of the data, from satellite reflectance (MERIS or MODIS) or measured in-situ:

$$
\text { Turbidity } \left.=0.54 \text { (non_algal SPM }+0.234 C h l^{0.57}\right)
$$

In this equation, non_algal SPM is in $\mathrm{mg}^{-1}$ and $\mathrm{Chl}$ in $\mu \mathrm{g} \mathrm{I}^{-1}$. In the study of Gohin (2011), which is based on an historical data set on in-situ observations, Turbidity, expressed in NTU (Nephelometric Turbidity Unit, U.S.E.P.A 180.1), is defined from the measurement of a broad spectrum incident light in the wavelength range $400-680 \mathrm{~nm}$, as one of a tungsten lamp, scattered at an angle of $90+/-30^{\circ}$.

Formula (1) is an approximation as non-algal SPM groups particles with very different sizes, shapes and refractive indexes. However, it gives an order of magnitude of the relative contributions of phytoplankton and other particles to the total SPM. For example, a chlorophyll concentration of $20 \mu \mathrm{g} \mathrm{I}^{-}$ ${ }^{1}$, which corresponds to a strong phytoplankton bloom, will generate a SPM concentration of about 1.3 $\mathrm{mg} \mathrm{I}^{-1}$; which is very modest compared to river plumes or coastal resuspensions under the action of waves.

Due to the limitations of our in-situ data sets (small number of samples) and the restricted capabilities of the high resolution sensors for investigating in detail the water column, we have decided to consider Turbidity as the representative of the water clarity. However, all the indicators of the water clarity are tightly related. Turbidity and SPM are particularly close, through their common relationship with the scattering property of the water. The Secchi depth is more sensitive to the absorption, which is itself linked to the SPM content but also to CDOM, particularly dense in low salinity waters.

\subsection{Turbidity retrieval}

Image processing techniques for retrieving turbidity differ between the two study sub-areas. For the Danube Delta coastal zone, a satellite data set containing 52 selected images from the Medium Resolution Imaging Spectrometer (MERIS) was processed. All images were acquired in full resolution mode $(300 \times 300 \mathrm{~m})$ and in the level 2 MERIS product. That means, for the water pixels, 13 spectral channels $(\lambda \approx 400 \sim 900 \mathrm{~nm})$ providing water leaving radiances $L w(\lambda)$. 
Turbidity maps from medium resolution data were obtained by application of the IFREMER empirical algorithms (Gohin 2011). Actually, it consists of a sequence of processing steps starting by calculating the chlorophyll-a concentrations from a look-up-table (Gohin et al. 2002). After that, a semi-analytical model (Gohin et al. 2005) relating the water-leaving radiance to the water constituents is used to retrieve the mineral SPM. Depending on the level of mineral SPM, the radiances in the green or the red parts of the spectrum are considered. Finally the turbidity (NTU) is obtained from Chl-a (related to the phytoplankton biomass) and mineral SPM.

Concerning the Danube Delta plain, the processing is more complex. First, due to the coverage limitation by the high-resolution sensors, 4 different satellites were used to compose a more complete data set. Second, since these sensors are not specially designed for water studies, their spectral bands are not adapted to perform water color algorithms like it is the case for the MERIS ones. Nevertheless, these satellites can provide precious and useful information about water quality. Several pioneer studies, most of them in the nineties, established relationships between satellite radiance from Landsat and SPOT optical sensors and water quality parameters, either for coastal areas (Forster et al. 1993; Froidefond et al. 1991; Pattiaratchi et al. 1994; Tassan 1993) and for lakes (Harrington Jr et al. 1992; Lathrop and Lillesand 1989). Some recent works used similar type of imagery to estimate SPM concentrations in the Danube River, with Landsat ETM+ (Onderka and Pekárová 2008) and in two French Estuaries - Gironde and Loire - with SPOT-4 data (Doxaran et al. 2002; Froidefond and Doxaran 2004). Onderka and Rodný (2010) proposed even a methodology for retrieving SPM from multispectral imagery adapted to the cases where in-situ measurements are not available for direct calibration.

For the area considered in the present study, in-situ measurements are scarce in both time and space. Consequently, a self-calibration approach was developed for retrieving turbidity inside the Danube Delta plain.

The visual interpretation of the high resolution data set (32 images) revealed that one specific lake (Belciug) presented very low radiance values for every image, indicating clear waters at all time. No event of sediment resuspension or phytoplankton bloom was detected for this lake. In fact, Belciug Lake, an old meander of Sf. Gheorghe branch, is the deepest lake in the delta (about $-7 \mathrm{~m}$ ) and it is surrounded by reed beds.

Based on the radiance of "invariant" targets (also called pseudo-invariant targets) in a given study area, it is possible to correct undesirable atmospheric effects from satellite images (Hadjimitsis et al. 2009; Schott et al. 1988). Invariant targets can also be used to calibrate satellite images presenting dissimilar illumination conditions (e.g. seasonal variations in temperate regions). In our research we selected two invariant targets inside the Danube Delta plain: the Belciug Lake and a portion of the Caraorman sand dunes. Contrasting with the Belciug waters, a small part of the Caraorman dunes presents always very high values of radiance. Field observations and long-term satellite analysis revealed that this section of Caraorman dunes remains dry even during huge flood periods (i.e. spring 2006 and spring-summer 2010). Equally important to prevent radiance variability, vegetation is negligible at the selected area, while other surrounding dunes are frequently recovered by xerophyte species.

As already reported, turbidity should be interpreted as a relative measurement, comparing the amount of light scattered by a sample with those scattered by a standard. Following this reasoning, the radiances of our two targets were used like empirical standards to calculate an index of turbidity. This method does not correct atmospheric effects itself, however it generates auto-calibrated indexes furnishing reliable information between different images as explained in the following paragraphs.

Our turbidity index $(\mathrm{TI})$ is obtained from radiances after standardization through Equation (2) 


$$
\mathrm{TI}_{(\mathrm{x}, \mathrm{y})}=\frac{\mathrm{R}_{(\mathrm{x}, \mathrm{y})}-\mathrm{R}_{(\mathrm{inv} \text { min })}}{\mathrm{R}_{\left(\mathrm{inv}_{\max }\right)}-\mathrm{R}_{\left(\mathrm{inv}_{\min }\right)}}
$$

where:

- $\quad I T_{(x, y)}=$ turbidity index for a pixel of coordinates $(x, y)$

- $\quad R=$ pixel radiance (related to turbidity through the backscattering coefficient)

- $\quad$ inv $v_{\min }=$ invariant target with minimum radiance (Belciug Lake)

- $\quad$ inv $v_{\max }=$ invariant target with maximum radiance (Caraorman dunes)

Two additional empirical constants were added to the former equation in order to create a turbidity index presenting adjusted percentage values. Moreover, to avoid single pixel potential errors, the radiances of the invariant targets were computed as an arithmetical mean (mR) from a $3 \times 3$ pixel window. The final turbidity index $(\mathrm{TI} \%)$ is expressed by the following equation:

$$
\mathrm{TI} \%_{(x, y)}=\left[\left(\frac{\mathrm{R}_{(\mathrm{x}, \mathrm{y})}-\mathrm{mR}_{\left(\mathrm{inv}_{\min }\right)}}{\mathrm{mR}_{\left(\mathrm{inv}_{\max }\right)}-\mathrm{mR}_{\left(\mathrm{inv}_{\min }\right)}} \times 100\right)+\mathrm{a}\right] \times \mathrm{b}
$$

where:

- $\quad a=$ first empirical constant (prevention of negative turbidity values)

- $\quad b=$ second empirical constant (optimization of percentage distribution)

After testing the pertinence of each spectral band (as well as of a few band ratios) to perform the turbidity index (results not shown here), the red band was chosen. The best fit of the red band to characterize the turbidity of Danube Delta waters is not truly surprising. Actually, pioneer research already indicated TM3 (red band of Landsat TM) as being highly responsive to variations in turbidity (Lathrop and Lillesand 1986). Laboratory studies also showed that the optimum wavelength for quantifying SPM is 550-650 nm (Novo et al. 1989). Froidefond et al. (2004), using field spectral measurements and SPOT imagery, showed that XS2 channel (red band of SPOT-4 HRVIR) is the most sensitive to changes in SPM concentrations ranging between 3.5 and $500 \mathrm{mg} \mathrm{I}^{-1}$. Furthermore, in agreement with data from other delta areas, Ferrari et al. (1996) found that the absorption due to yellow substances is negligible beyond $600-650 \mathrm{~nm}$. Finally, there is also a technical advantage related to the red band; the spectral intervals of the selected optical sensors are almost similar ( $\approx 610-690 \mathrm{~nm})$.

Lastly, a phytoplankton index was developed to estimate the biological contribution on global turbidity. When phytoplankton concentration is high enough to change turbidity patterns in the lakes, its presence can be easily detected by checking up the satellite images. In those cases, the image analyst determined different levels (usually 3 or 4 ) of phytoplankton biomass by adding reference points, also called "pins". After examining the spectral histograms of the reference points and using pre-established empirical thresholds, the areas where the turbidity is mostly caused by phytoplankton are extracted. This procedure uses spectral information from green, red and infrared bands to separate areas containing clear water, mineral turbid water and biological (phytoplankton) turbid water. Only for these "phytoplankton dominated areas" the former turbidity index is recalculated by introducing a phytoplankton coefficient in Equation 2. It generates a second image product, named phytoplankton 
index. A third product can be created from the combination of the turbidity index with the phytoplankton index, this product was named "fused product".

\section{Results and discussion}

\subsection{Assessment and validation}

In order to assess the reliability of turbidity products with field data, both medium and high spatial resolution TI were compared to in-situ measurements. Although turbidity in-situ measurements are not available for the Danube Delta waters, some match-up comparisons were possible using transparency and SPM field data (fig. 4). 

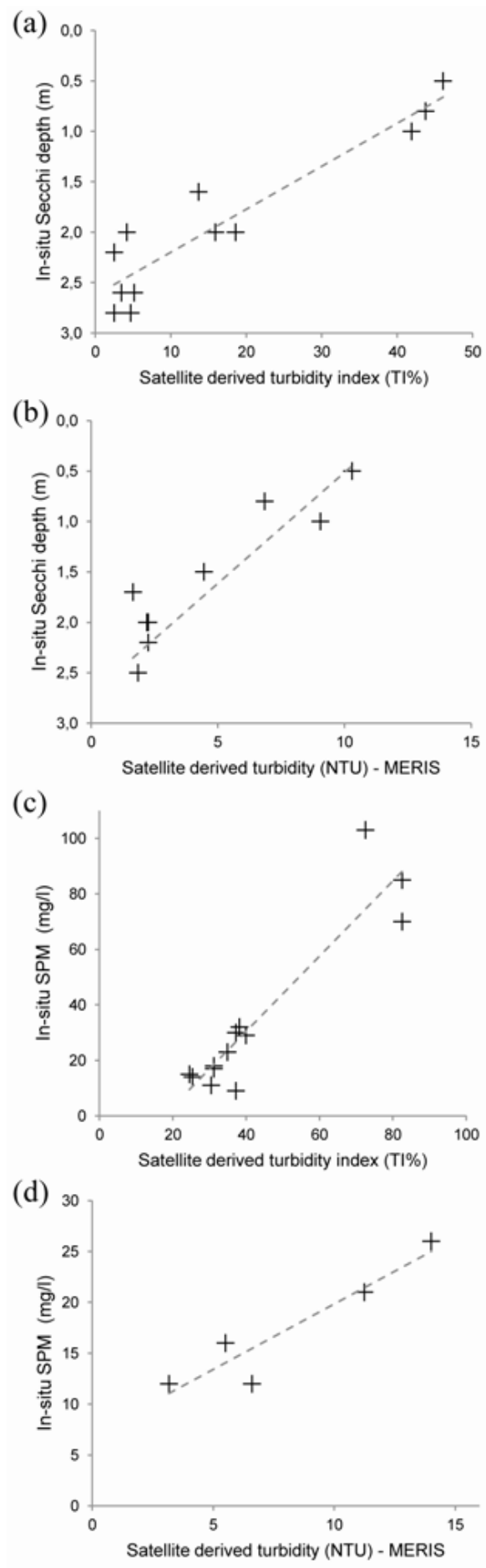

Fig. 4. Scatter plots comparing satellite derived turbidity with observed transparency $(a, b)$ and in-situ SPM (c, d).

The scatter plots (fig. 4) comparing satellite derived turbidity and in-situ transparency ( $a, b)$ showed a good correlation for both types of imagery $\left(R^{2}=0.87\right.$ for ' $a$ ' and $R^{2}=0.66$ for ' $b$ '). For high spatial resolution images (a), Secchi depth observations from six lakes and five coastal points were compared with satellite turbidity indexes. Three satellite images were used: 07/21/2009, 06/04/2010 and 06/11/2010. The maximum time gap accepted between field observation and satellite acquisition was of 48 hours. For MERIS images (b), all Secchi depth observations were made in the coastal zone and 
during the same day of the satellite acquisition. Two satellite images were used: 07/21/2009 and 09/16/2009.

The correlations between in-situ SPM and satellite derived turbidity (fig. 4) were also high $\left(R^{2}=0.86\right.$ for ' $c$ ' and $R^{2}=0.88$ for ' $d$ '). As already mentioned, the entire dataset of in-situ SPM was acquired at three river branch stations. The maximum time gap considered between in-situ SPM and high spatial resolution images (c) acquisition was of 120 hours for periods with no substantial river fluctuation and 48 hours otherwise. Five satellite images were used: 07/05/2006, 07/16/2007, 08/04/2007, 09/07/2007 and $02 / 02 / 2008$. Actually, the turbidity of the branches generally shows a more stable pattern than the coastal areas or lakes connected to river channels. Nevertheless, the comparison with MERIS derived turbidity (d) was more restricted, and only the SPM data for Sf. Gheorghe branch was used. Since the Sf. Gheorghe station is situated very near (about $1 \mathrm{~km}$ ) of the branch mouth, the turbidity at this point should be comparable to the turbidity found in the inner part of the river plume (which can be detected by the MERIS sensor). The maximum time gap considered between in-situ measurement and satellite acquisition was of 48 hours. Five satellite images were used: 03/11/2008, 06/21/2008, 07/20/2008, $10 / 17 / 2008$ and $12 / 10 / 2008$. This last example (scatter plot 'd' on fig.4), showed a linear relationship very near to the general relation between in-situ turbidity and SPM (Turbidity $=0.54$ SPM) observed by Gohin (2011) in the coastal waters of the Bay of Biscay and the English Channel .

As seen in figure 4, direct match-up confrontations were possible only for few points and dates. In order to compare and test the validity of the turbidity products in a more dynamical approach we establish two temporal series for periods when more frequent in-situ and satellite data were available (fig. 5). The temporal evolutions of in-situ SPM were plotted in parallel to satellite derived turbidities, first for high spatial resolution images and second for MERIS images. The results showed a good reliability between the temporal series, both seem to be greatly influenced by Danube water level fluctuations. 

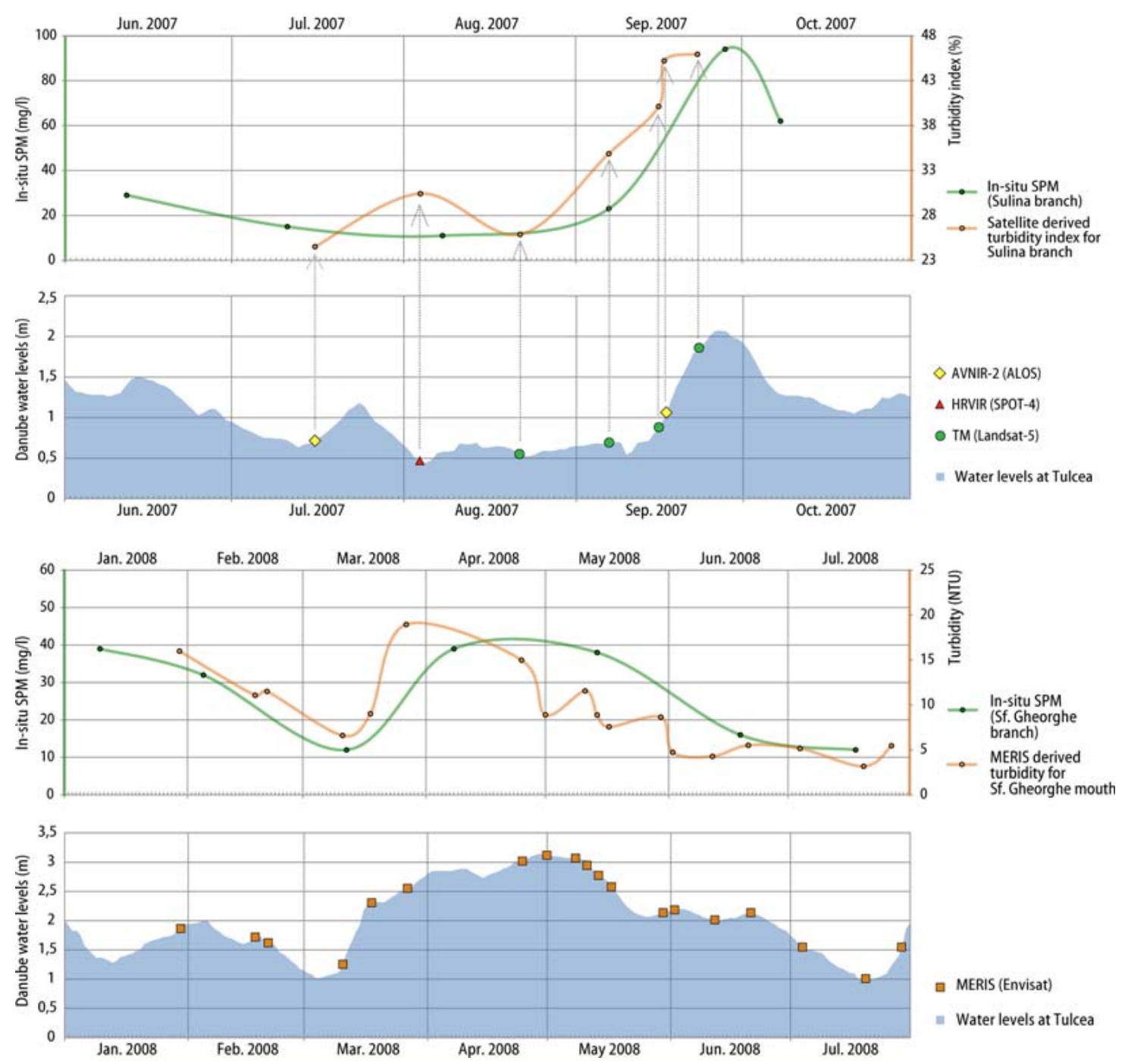

Fig. 5. Temporal series of satellite derived turbidity versus in-situ SPM at Sulina and Sf. Gheorghe stations.

The first temporal series in figure 5, corresponding to the summer 2007, is characterized by extremely low water levels and therefore minimal liquid and solid discharges. During September 2007, a progressive elevation of the Danube water level immediately changed the water quality of the river. Satellite derived turbidity and in-situ SPM curves reflected accurately this shift. The second temporal series in figure 5 correspond to the first seven months of 2008, a "typical" year. The spring flood pulse can be easily observed, as well as the related augmentations on satellite derived turbidity and in-situ SPM. However, a higher variability of the satellite derived turbidities was observed for this time series. This higher variability is likely to be caused either by the changeable conditions of the mouth area (where MERIS turbidity was extracted) or by the presence of some masked pixels avoiding the estimation of the turbidity exactly at the mouth zone.

After having verified the good correlation between satellite-derived turbidity, in-situ transparency and in-situ SPM, the inter-comparability of the turbidity products was independently verified. The comparison was carried out with a pair of satellite images acquired on the same day; one by the MERIS sensor and another one by the AVNIR-2 sensor (fig. 6). 

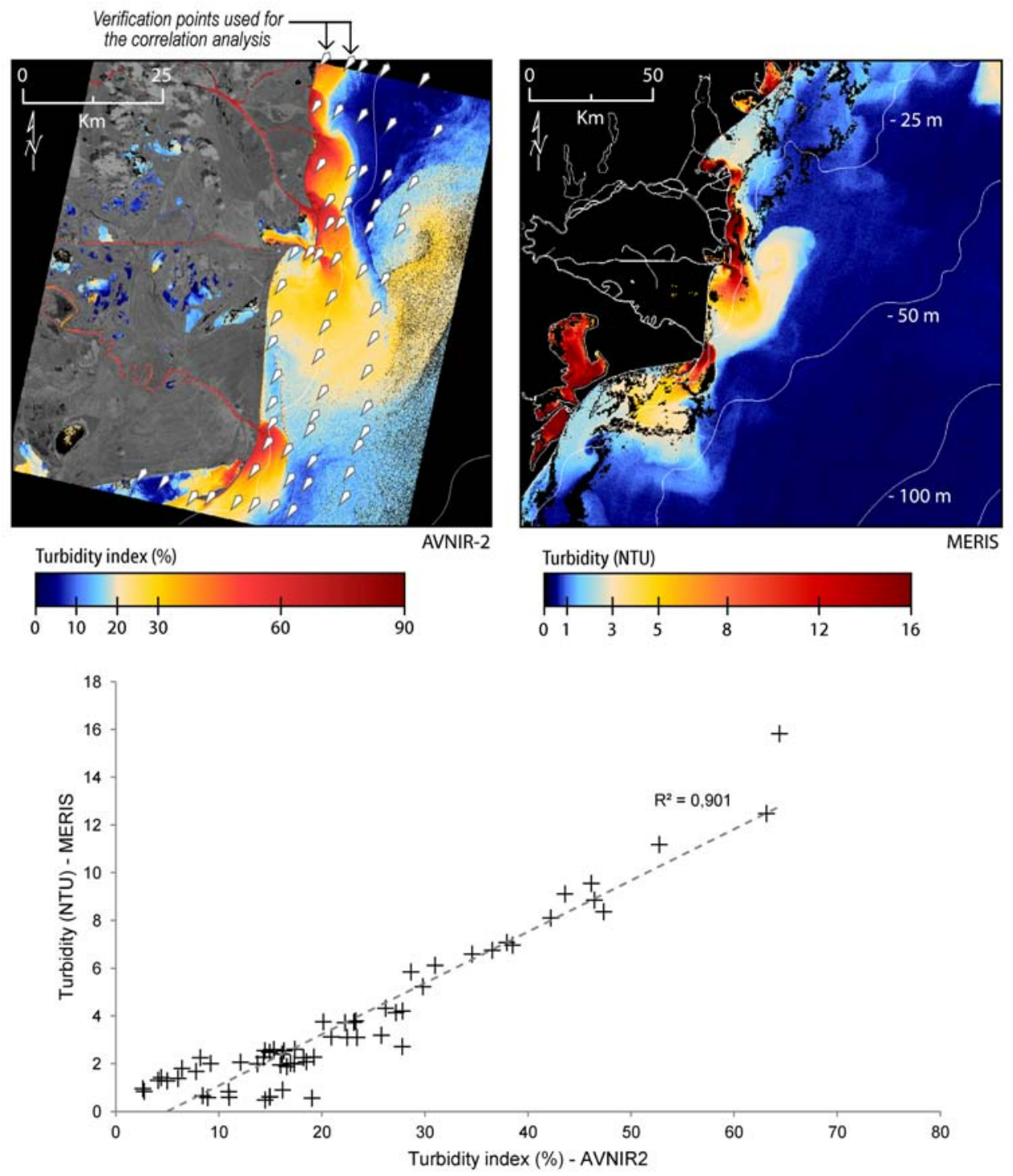

Fig. 6. Inter-sensor turbidity assessment for two satellite images (AVNIR-2 and MERIS) acquired at the same day - 21th July 2009 - with about 40 minutes of interval. The correlation (63 verification points) between the two independent turbidity products was particularly high $\left(R^{2}>0.90\right)$.

As seen in figure 6, the two independent turbidity products notably overlap themselves. The shape and the extent of the turbid plumes are very similar for both products. The statistical approach confirms the visual confrontation. The linear regression, calculated from 63 verification points, displays a particularly high coefficient of determination $\left(R^{2}>0.90\right)$. Another temporal coincidence (between MERIS and ETM+) was observed on 23th May 2006. However, the very high intensity of sun-glint on the ETM+ image did not allow an additional inter-sensor comparison.

\subsection{Seasonal turbidity patterns}

Integrated analysis of the satellite data set, comparing side-by-side delta plain and coastal zone turbidity spatial evolutions, allowed us to recognize some seasonal turbidity patterns. Figure 7 shows three characteristic seasonal turbidity situations for Danube Delta waters observed during 2008 - a "typical" year with regard to hydrological variations. 
During winter, the Danube River usually presents quite high levels of turbidity, even if the liquid discharge is not particularly important. When the river turbid waters reach the Danube Delta, if the lakes and river distributaries are not frozen (lakes remain frozen around 5 weeks per year), important amounts of suspended matter are carried toward the lakes. In this season, turbid waters can penetrate really far inside the hydrographic sub-units, reaching a great number of lakes not directly connected to river distributaries. A good example (fig. 7 - upper left) is given by the turbid inputs coming from Uzlina canal and spreading all over the Uzlina Lake surface. From this lake, a turbid plume is formed and crosses the Isac Lake. Finally, from this latter lake, turbid waters are still exported away, reaching the small lake of Harasimova, located more than $9 \mathrm{~km}$ (boat travel distance) far from the Sf. Gheorghe former meander.

In the coastal zone, winter conditions usually generate highly turbid plumes at the Danube Delta mouths. However, powerful coastal currents are able to limit efficiently the extent of the river plume. The selected MERIS winter image (fig. 7 - upper right) clearly shows that the river plumes are rapidly oriented southwards. Consequently, the offshore river plume propagation, in front of the main river mouths, is limited to less than $15 \mathrm{~km}$ from the delta shoreline. Beginning from the south of Sacalin Island the river plume presents a bigger offshore extension, reaching about $28 \mathrm{~km}$ from the coast. 

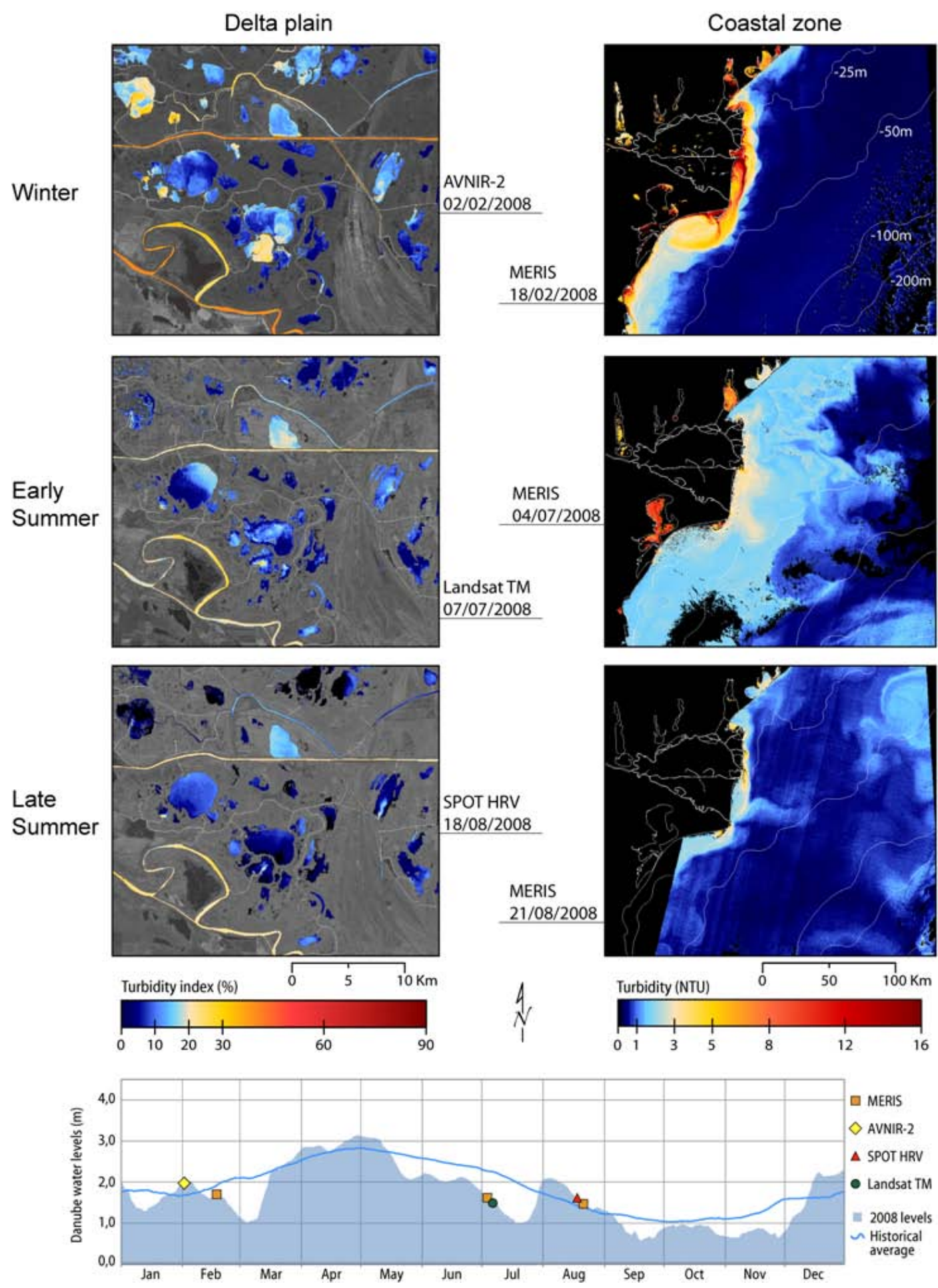

Fig. 7. Typical seasonal variations of turbidity for the Danube delta plain and coastal zone.

During the spring, turbidity patterns became much more multifaceted and it is quite hard to select a single typical situation. Usually, the Danube water level increases quickly from March and the maximum levels are registered during April and May. However, the lake's turbidity starts to decrease from April and most of the lakes present clear waters during spring maximum water levels. The exceptions are the lakes located near the Danube branches or major distributaries (affected by river overflow - especially inside Şontea-Furtuna sub-unit), as well as the lakes promptly connected to 
regular inflow points (indicated on fig.2). Even though, the turbid plumes generated at the inflow points are much smaller than those described for the winter. Consequently, turbid waters coming from the river generally do not overpass the limits of the first lake and do not penetrate much inside the hydrographic sub-units.

At the coastal zone, the rise of the Danube water level does not correspond systematically with an augmentation of the river plume offshore extent, which remains greatly limited by strong coastal currents throughout March and April. However, short periods (about a week) of considerable plume offshore expansion (more than $40 \mathrm{~km}$ ) can already be observed since April. Indeed, both for the lakes and the coastal zone, spring represents a transition: in the lakes, river-induced turbidity tends to decrease and to affect a reduced number of lakes (those exposed to overflow or connected to regular inflow points), whereas in the coastal zone the river plume tends to increase its seaward expansion.

Maximum river plume offshore extents, reaching more than $70 \mathrm{~km}$ far from the Danube mouths (as showed in fig.7 - middle right), are usually observed from the second half of May until the first half of July. Once the river plume is well developed, it can remain in a quite large and stable zone during few weeks. This well marked seasonal behavior does not seem to be closely related to the hydrological conditions of the Danube River, since it has been observed for all the analyzed period (4 dissimilar years with regard to water levels). Additionally, the late spring-early summer period is characterized by the decrease of water levels and river discharge, which cannot sustain the hypothesis of turbidity control solely by the Danube river inputs in the coastal zone.

Inside the delta plain, riverine overflows reaching lakes become rare in early summer. At the same time, the turbid inputs provided by regular inflow points tend to diminish with the decrease of the Danube water levels (as seen in fig. 7 - middle left). Conversely, some lakes start to present highly turbid waters since June, an evolution that cannot be directly associated to the river-inputs. In fact, this phenomenon includes a certain number of "isolated" lakes, located far either from inflow points or overflow areas.

In late summer, the presence of turbid waters in isolated lakes is still well represented, while the impact of turbid inflow points becomes really modest, even for directly connected lakes (i.e. Uzlina and lacob lakes on fig. 3 - lower left). The reduced turbid contribution from the Danube River is also observed in the coastal zone, in particular during August. The waters flowing out of the mouths present low turbidity and the spatial extent of the plumes barely exceeds $10 \mathrm{~km}$ from the coastline (fig. 3 - lower right).

The described pattern prevails generally until September. Afterwards, less stable conditions are observed especially for the coastal zone. During fall, turbidity values for the river plume tend to increase and its seaward expansion is usually greater than throughout summer, however important extension events (more than $40 \mathrm{~km}$ ) are restrained to short periods of time.

Finally, delta plain lakes during fall present a turbidity pattern rather similar to those described for summer. Overflows are infrequent during this period and the influence of inflow regular points on lacustrine turbidity remains limited. Although, a great number of lakes (including isolated ones) presents highly turbid waters with turbidity values often bigger than those recorded during summer.

\subsection{Turbidity controlling processes}

The simultaneous analysis of the turbidity spatial patterns revealed that the river control hypothesis fails to explain several dynamics observed either in delta plain lakes or in the coastal zone. Indeed, other mechanisms are acting jointly with the Danube River inputs all over the seasons, ensuring an elevated variability of turbidity in space and in time.

In that light, the phytoplankton development is an important factor, under certain conditions, to understand turbidity evolutions. Figure 8 illustrates the contribution phytoplankton biomass can engender during the beginning of fall. 


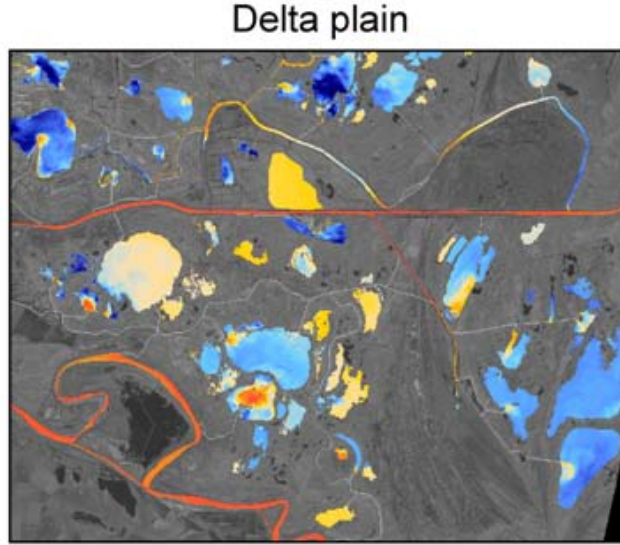

Turbidity index (\%)
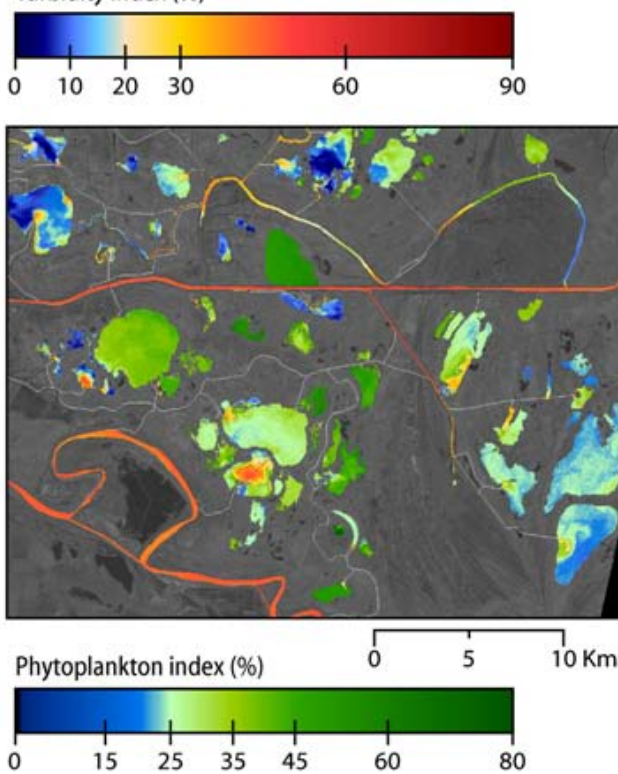

AVNIR-2

$17 / 09 / 2007$

\section{Fused product} (turbidity + phytoplankton)

$9 / 2007$
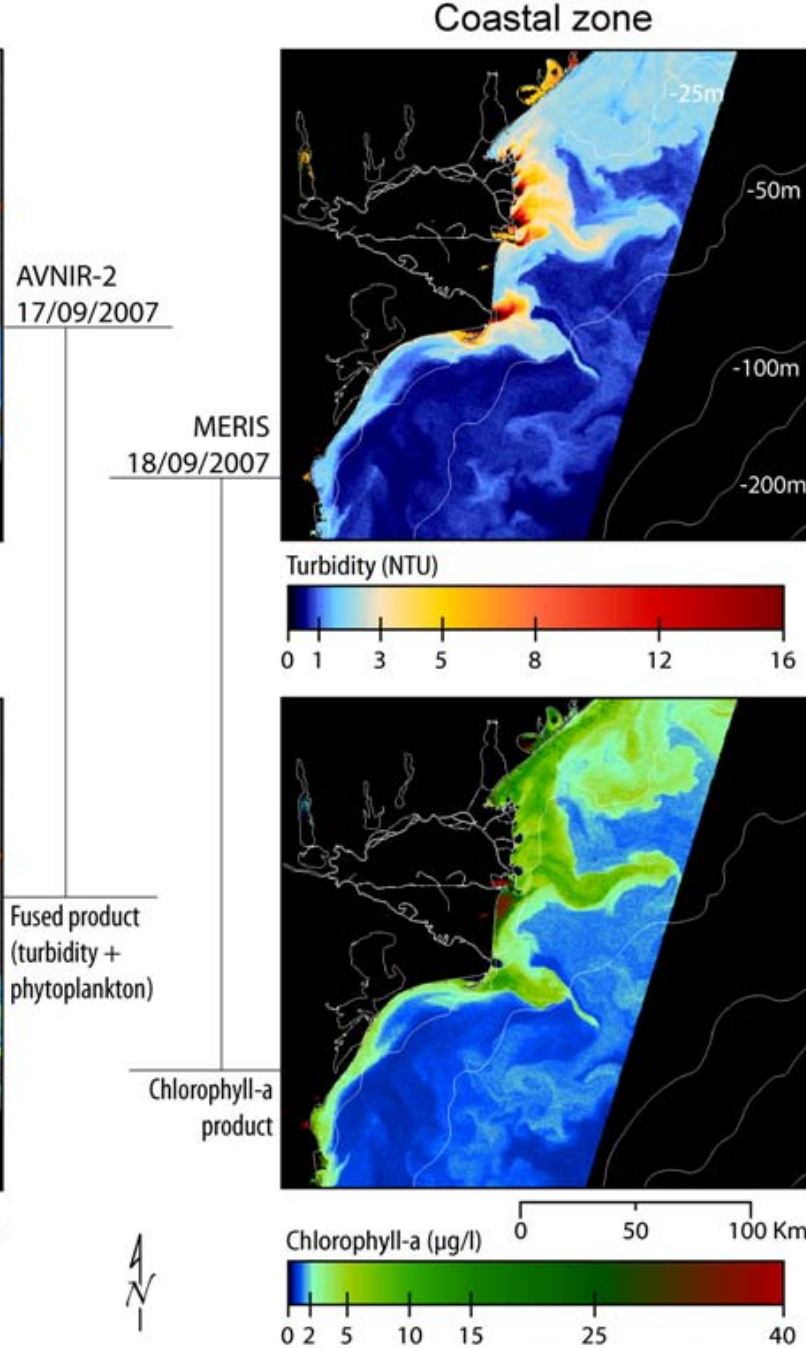

Fig. 8. Phytoplankton contribution to global turbidity.

As seen in the figure 8 (upper left), most of the lakes over the Delta plain exhibit highly turbid waters (yellow and orange tints), including many isolated and quite small ones (i.e. Harasimova, Cuibul cu Lebede, Lebedea, Chiril, Taranova). Analyzing the phytoplankton contribution (lower left - fused product) it becomes easier to understand the complex pattern of turbidity presented before. In fact, this AVNIR-2 image illustrates the maximum phytoplankton development observed for the entire data set of high resolution satellite images (2006-2009). River turbid inputs are well represented at the regular inflow points (orange-red tints), whereas clear waters (dark blue) are rare and only sparsely represented in few lakes, such as Furtuna and Radacinos. All the other lakes are dominated by massive development of phytoplankton; the spatial spread of different levels of biomass (corresponding to green tints) is also noticeable.

According to the phytoplankton spatial evolution observed in the satellite images, huge phytoplankton biomass can enhance significantly the turbidity (TI values higher than 15\%) in the lakes from June to October. No massive phytoplankton development was observed during spring. Hence, phytoplankton induced turbidity plays an important role and can explain rapid turbidity evolutions in a great part of the delta plain lakes during summer and fall. The satellite results match with qualitative field observations carried out during the summers of 2007, 2008 and 2009 and previous studies dealing with phytoplankton dynamics on the Danube Delta (Coops et al. 2008; Coops et al. 1999; Oosterberg et al. 2000). Those authors, using in-situ surveys realized in 1997-1998 and 2001-2002, suggested that the 
phytoplankton seasonal behavior on the Danube Delta lakes is characterized by a small peak of production in March-April followed by a more important production in July-November.

In the coastal zone, phytoplankton contribution to the global turbidity is more delicate to analyze since the production areas usually overlap the spatial extent of the turbid plume (as seen on fig. 8). The most important concentrations of chlorophyll-a are observed over the border of the turbid plume or close to the coast; both areas of moderately high mineral SPM. The chlorophyll-a concentration (based on satellite and in-situ observations) in those areas is rarely superior to $25 \mu \mathrm{g} \mathrm{I}^{-1}$, while in the lakes the concentration can frequently overpass $50 \mathrm{\mu g} \mathrm{I}^{-1}$ (Oosterberg et al. 2000) and even reach $110 \mu \mathrm{g} \mathrm{I}^{-1}$ (Vadineanu et al. 1992). Yet further research is needed on this topic, it is likely that phytoplankton contribution to global turbidity is less important in the coastal zone than in the lakes.

A second important factor affecting turbidity patterns is the presence of aquatic macrophytes. This factor is proper to delta plain lakes; in the coastal zone only Musura and Sacalin bays are noticeably influenced by macrophyte growth. Inside the delta plain, macrophyte development starts from April for almost all lakes, but its biomass remains reduced until the beginning of May. Since May several lakes starts to present dense communities of submerged and floating macrophytes that act as effective "filters" of suspended matter coming from the river distributaries. This factor can somewhat explain the low values of turbidity observed in the lakes during the high water levels of late spring and early summer. Nevertheless, the spatial distribution of the macrophytes is unequal throughout the hydrographic sub-units; Şontea-Furtuna and Gorgova-Uzlina are most heavily occupied by macrophytes, followed by Matiţa-Merhei and, at last, Roşu-Puiu. In general, macrophytes spatial patterns (in particular for floating and near-surface communities) are quite stable from the end of May until the end of September. Substantial decomposition of the macrophytes in most of the lakes starts in October and it is likely that the "role of filter" is worthless after November. Detailed information on the temporal dynamics of the Danube Delta macrophytes is scarce; nevertheless our satellite results match in several points with previous studies (Coops et al. 1999; Cristofor et al. 2003; Hanganu et al. 2002). Coops et al. (1999) suggested that summer algal blooms may cause high turbidities and, as a result, the submerged macrophytes disappear from many lakes in late summer. Even if the detection of submerged communities of macrophytes (deeper than $50 \mathrm{~cm}$ from the water surface) is almost impossible with optical images in the Danube Delta lakes (high concentrations of yellow substances), our results can furnish some indirect indications. It is hypothesized that continual high concentrations of phytoplankton (i.e. phytoplankton index values higher than $30 \%$ during several weeks) is the cause of the disappearance of submerged plants due to light limitation. In contrast, lakes presenting clear waters or ephemeral algal blooms throughout summer may support dense communities of submerged macrophytes up to October.

Beside river inputs, phytoplankton and macrophytes development, turbidity elevation can be generated by winds and waves. As a global result (from the combined analysis of imagery and wind data), the coastal zone is much more affected by sediment resuspension than are lakes. Even though, only small portions of the coastal zone are exposed to important events of resuspension. In fact, resuspension has been noticed almost exclusively for very shallow areas (less than $20 \mathrm{~m}$ depth) which are recurrently less than $5 \mathrm{~km}$ far from the coast. Those resuspension events are clearly related with wind speed and direction (and consequently wind-induced waves). Based on our observations, average wind speed should be higher than 15 knots to engender well represented sediment resuspension on satellite images; the north coast (Chilia sub-delta) and the central coast (between Sulina and Sf. Gheorghe branches) are much more affected by Northeastern and Eastern winds while the south coast (south of Sf. Gheorghe) is exposed mainly to Southern and Southeastern winds. Our results agree with more specific and local studies, such as Dan et al. (2009). These authors affirmed that local wind stress can be considered the very dominant source of waves reaching the central and south sectors of Danube Delta coast. Dan et al. (2009) calculated also that the closure depth along these sectors ranged from 5.0 to $11.6 \mathrm{~m}$, what means that even during high wave episodes (generated by northern and southeastern winds with speeds higher than 60 knots) they will not affect sediments deposited beyond the referred depths. 
In lakes and protected bays, the presence of macrophytes seems to prevent efficiently the effect of the wind on bottom sediments. During spring (few or no macrophytes) resuspension was observed both in big lakes and in coastal bays. In contrast, throughout the summer (massive development of macrophytes) no resuspension was noticed; we should add that powerful winds are less frequent in summer. During fall (still considerable presence of macrophytes), some resuspension was observed but only for one single date when average wind speed was of 24 knots.

In spite of the influence on sediment resuspension, wind has a major impact on river plume shape and extent. The time series analysis of the river plume spatial patterns reveals that the plume shape reacts really fast to wind conditions (fig.9).
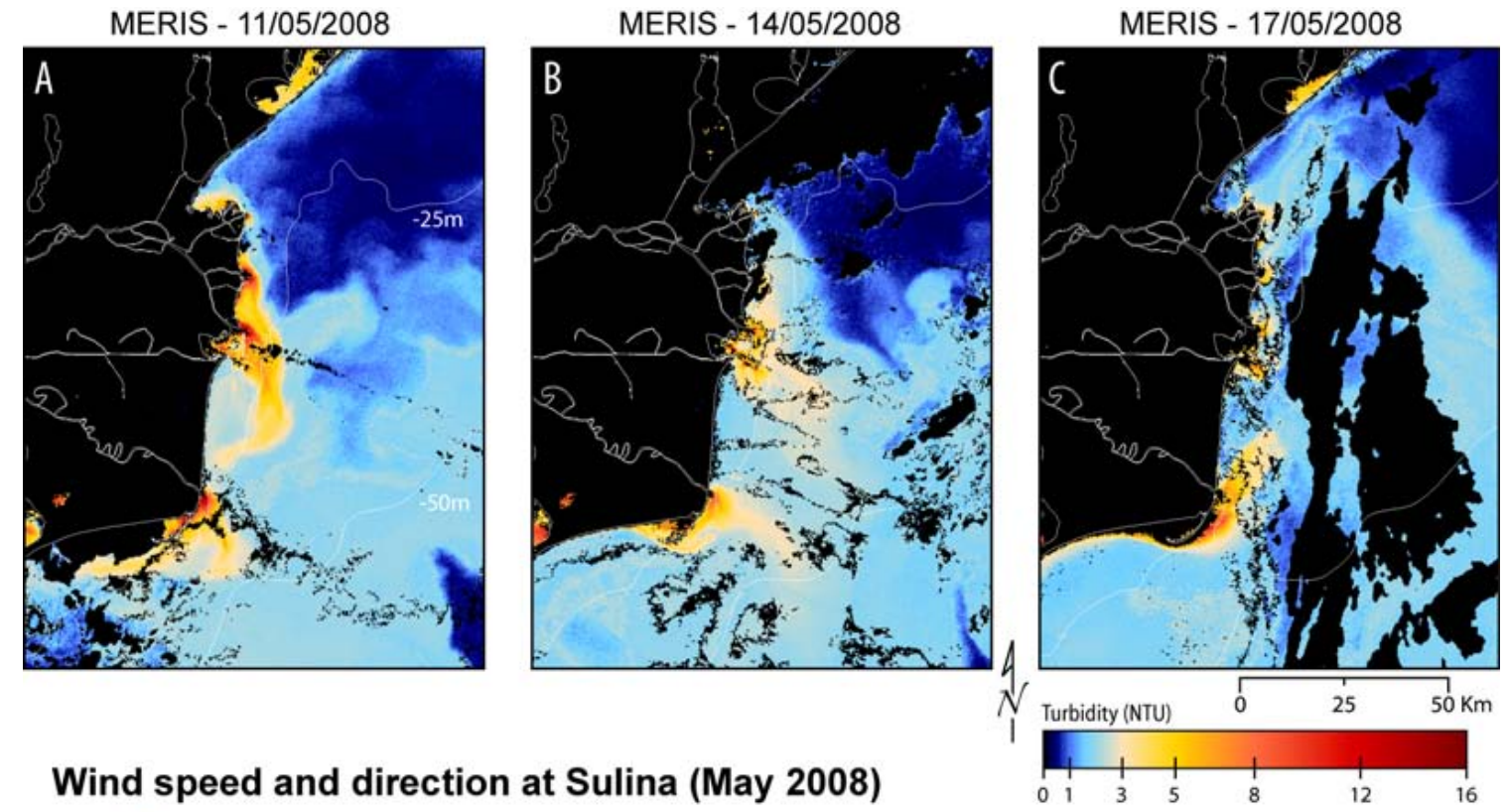

\section{Wind speed and direction at Sulina (May 2008)}

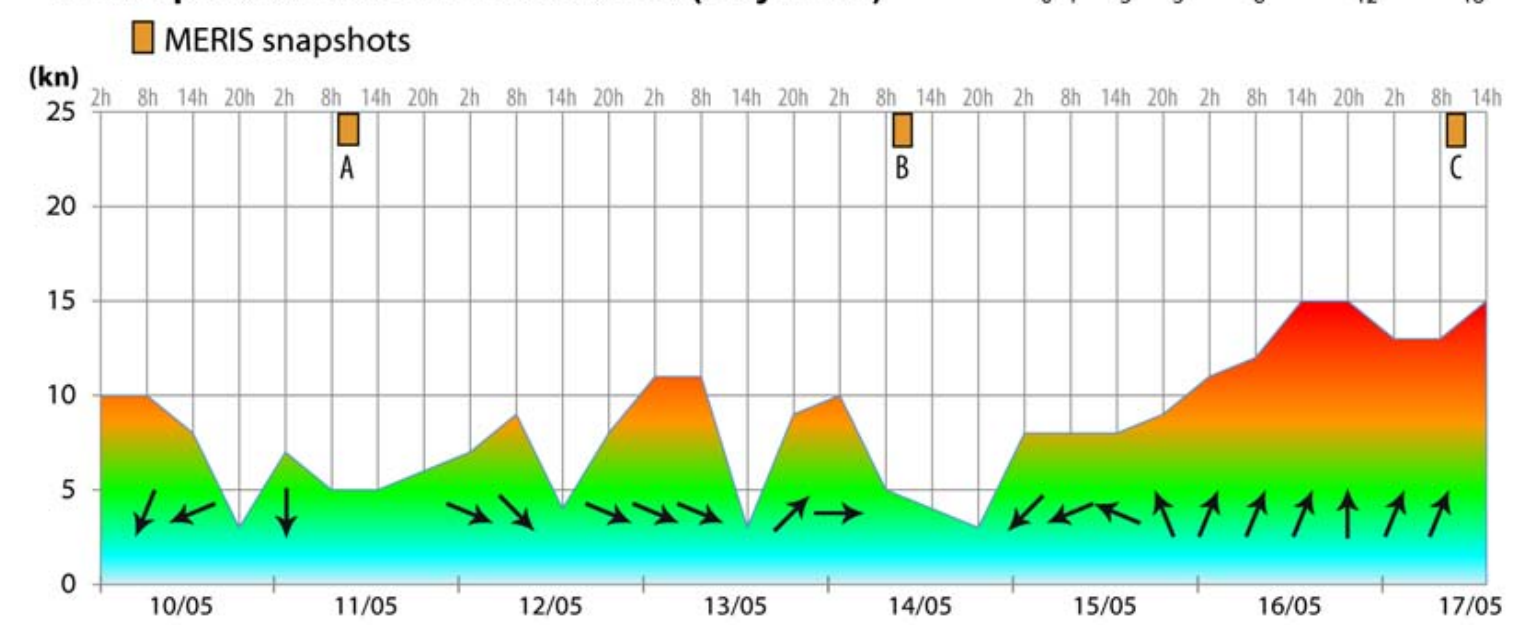

Fig. 9. Wind effects on river plume shape and orientation along the Danube Delta seaside.

The figure 9 shows, through three MERIS snapshots separated by a 3-days interval, the clear effect of the wind on the river plume orientation and spatial dynamics. The period displayed on the graphic began with winds coming mainly from NE-N directions; as a consequence the river plumes were clearly oriented southwards (snapshot A). Less than 24 hours after the first snapshot, wind turned NW and kept a Western component until the second snapshot (B). Those two days of seaward winds were enough to change the orientation of the plumes and to enhance their offshore extents. Seaward winds ceased after the second snapshot and landward winds flowed for one day before turning northwards. 
Less than 48 hours of steady winds from south were enough to drive the turbid plumes northwards (C), inverting completely the spatial pattern observed six days before (A).

The general orientation of the turbid plumes was clearly associated with the prevailing wind conditions that preceded every MERIS snapshot for the analyzed period. A more detailed analysis showed that the wind conditions observed for the 12-24 hours before the snapshot were already "imprinted" on the inner part of the main plumes, whereas the wind conditions of the preceding 48-24 hours were often noticeable over the outer parts of the plumes. Those results agree with the statements of Tolmazin (1985) who estimated that the time of dynamic response in the Black Sea Northwestern coastal waters to average steady wind ranges from 10 to 15 hours. Danube plume dynamics during 2002 and 2004 were discussed by Karageorgis et al. (2009). Although thermal stratification and river load influence the development of the river plume, it was found that wind conditions before and during the sampling play an important role on the plume observed patterns. Similar conclusions were pointed out by Ragueneau et al. (2002) for 1995 and 1997. Also, several aspects of our remote sensed observations match with recent results from model simulations (Dinu et al. 2011) used to evaluate the influence of wind and river discharge on the current circulation along the Romanian coast. The spatial patterns of current velocity under simulated conditions exposed by Dinu et al. (2011) can be easily recognized on our MERIS turbidity products by analyzing the Danube plume shape, extent and internal variations of turbidity.

\subsection{Turbidity inter-annual variability}

Although seasonal turbidity patterns have been described, as well as the main turbidity controlling factors, the Danube Delta waters can present really different turbidity patterns from one year to another. While this is true that the initial hypothesis of river control failed to explain the turbidity spatial patterns, we observed that very different hydrological conditions for distinct years (as 2006 and 2007) clearly affect turbidity spatial patterns. Figure 10 shows two contrasted situations for a similar period of the year but where delta plain and coastal zone turbidity patterns were particularly opposed. 

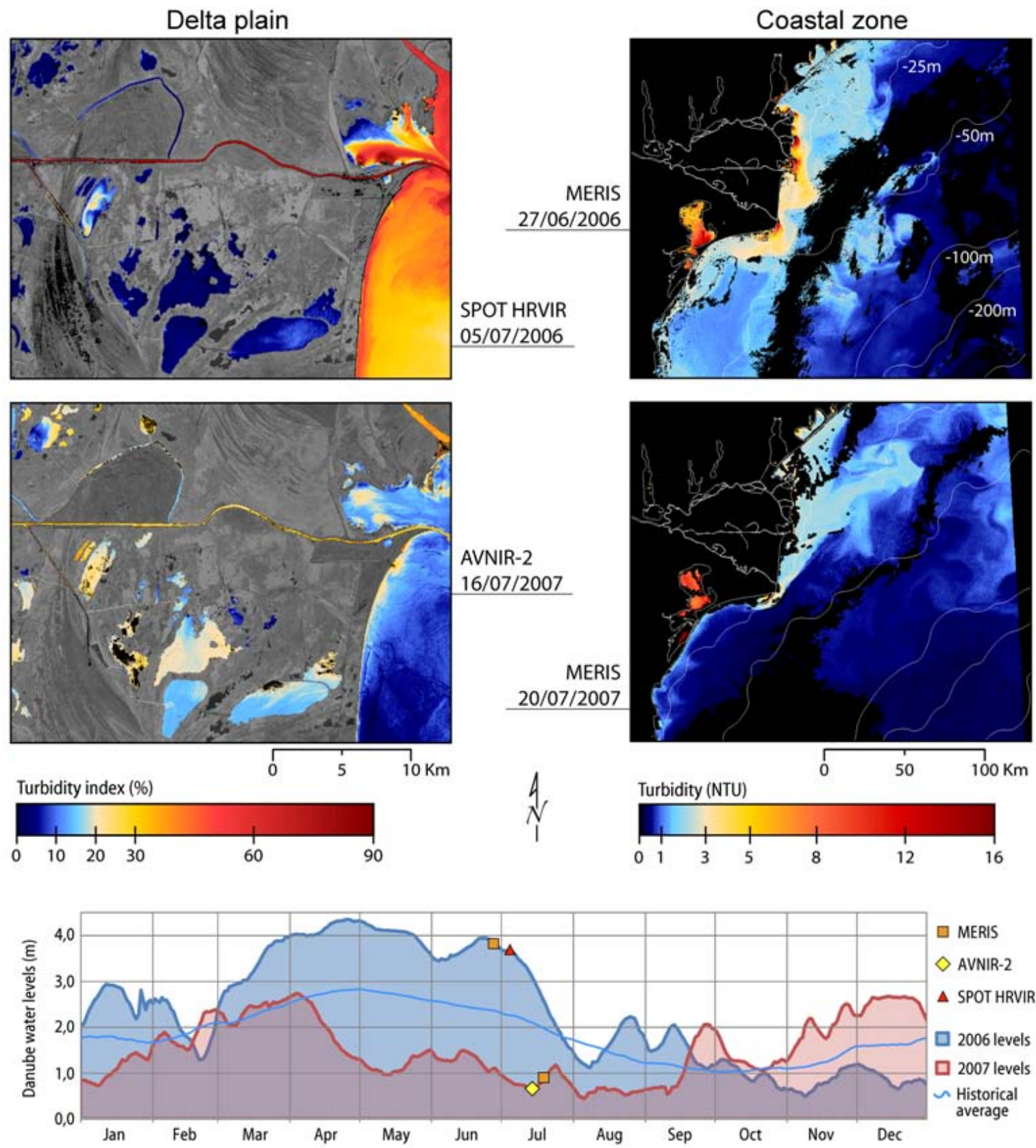

Fig. 10. Opposite turbidity evolutions in the delta plain and the coastal zone

During 2006, the spring flood pulse was "stretched" until midsummer. As a consequence, exceptionally high water levels were registered for the first two images showed on figure 10 (3.9 m on 27/06/2006 and $3.7 \mathrm{~m}$ on 05/07/2006). Also, SPM measured at Sulina branch presented exceptionally high values (178 $\mathrm{mg} \mathrm{l}^{-1}$ on 13/06/2006 and $85 \mathrm{mg} \mathrm{I}^{-1}$ on 11/07/2006) during summer. In fact, the in-situ SPM registered in June 2006 was the highest value of the entire ICPDR data series (1997-2008) and it was significantly higher than those recorded in April and May 2006 (48 and $33 \mathrm{mg} \mathrm{I}^{-1}$ respectively). These exceptionally turbid river waters were accurately detected by our turbidity algorithms, as seen on figure 10 (values higher than 85 TI\% at Sulina branch and around 14-16 NTU near the river mouths). However, exceptionally high water levels and river turbidities were not able to enhance the turbidity of the lakes. Almost all lakes presented very clear waters (less than 5 TI\%) with the exception of lacob Lake, Uzlina Lake and few other small lakes inside the Şontea-Furtuna sub-unit; none of them was phytoplankton dominated. Oosterberg et al. (2000) suggested that flood pulse intensity during spring, leading to high summer inflow of "reed waters" to lakes, may prevent massive development of 
phytoplankton by mechanisms such as flushing, humic acids or nitrogen limitation. Thus, steady high water levels are likely to have an important negative impact on phytoplankton growth during summer.

For a more detailed analysis of the coastal zone, we might consider two parts of turbid plumes; the inner plume, with turbidities higher than 3 NTU, and the outer plume, with turbidities ranging between 1 and 3 NTU. The inner plume, as a result of elevated solid and liquid river discharges, was well developed in the summer 2006 (as seen on the MERIS snapshot). Although the plumes presented a noticeable southward component (matching with wind directions prior to the MERIS snapshot) theirs seaward expansions reached distances between 10 and $20 \mathrm{~km}$ far from the coast. The outer plume, exhibiting a more homogeneous spatial distribution, presented a maximum offshore extent of about 60 $\mathrm{km}$.

During 2007, the spring flood pulse was almost inexistent; the Danube water level dropped since the beginning of April and remained low (around $1 \mathrm{~m}$ ) throughout the entire summer. Very low in-situ SPM were recorded at Sulina branch (15 $\mathrm{mg} \mathrm{l}^{-1}$ on 11/07/2007 and $11 \mathrm{mg} \mathrm{l}^{-1}$ on 08/08/2007). Our algorithms also accurately detected these low levels of river turbidity, as seen on fig. 10 (values around $30 \mathrm{TI} \%$ at Sulina branch and barely higher than 5 NTU near the river mouths). Conversely, turbidities observed in lakes were particularly high; i.e. $\sim 22 \mathrm{TI} \%$ for Lumina, $\sim 24 \mathrm{TI} \%$ for lacob and $\sim 38 \mathrm{TI} \%$ for Zapadna, a small lake situated nearby the lacob Lake. All the turbid lakes in July 2007 (fig. 10) were "phytoplankton dominated". In the coastal zone, the inner plume was very limited (barely reaching distances of $5 \mathrm{~km}$ from the coast) and clearly oriented northeastward (in accord to the wind directions prior to the MERIS snapshot). The outer plume was also noticeably modeled by the wind, presenting an elongated shape oriented in the northeast direction and reaching more than $75 \mathrm{~km}$ far from the Delta north coast.

\section{Conclusions}

Turbidity retrieval methods presented in this research were developed and applied on different types of optical satellite data. Our two turbidity algorithms, adapted to spatial and spectral characteristics of the sensors, furnished reliable and inter-comparable information allowing simultaneous analysis of the Danube Delta waters since the apex of the delta up to several tens of kilometers inside the westernnorthwestern Black Sea. Our results showed a dissimilar comportment between waters inside the lakes and in the Black Sea coastal zone. River discharge is an important factor to explain lacustrine and coastal turbidity, but it is clearly not enough. Other factors such as phytoplankton development, wind stress, sediment resuspension and presence of aquatic macrophytes participate in the turbidity control of the Danube Delta waters. The turbidity controlling processes are not acting in the same manner over the whole study area and they can present different levels of importance, even inside each sub-area (delta plain and coastal zone). The integrated space-time approach was essential to recognize and correctly interpret the differential effects engendered by the turbidity controlling processes. This integration, materialized in our research by the use of different spatial scales (fig. 11) and using data from 4 dissimilar years with regard to water levels, revealed to be very useful for understanding seasonal patterns and to distinguish the relative importance of controlling factors all over the study area. 


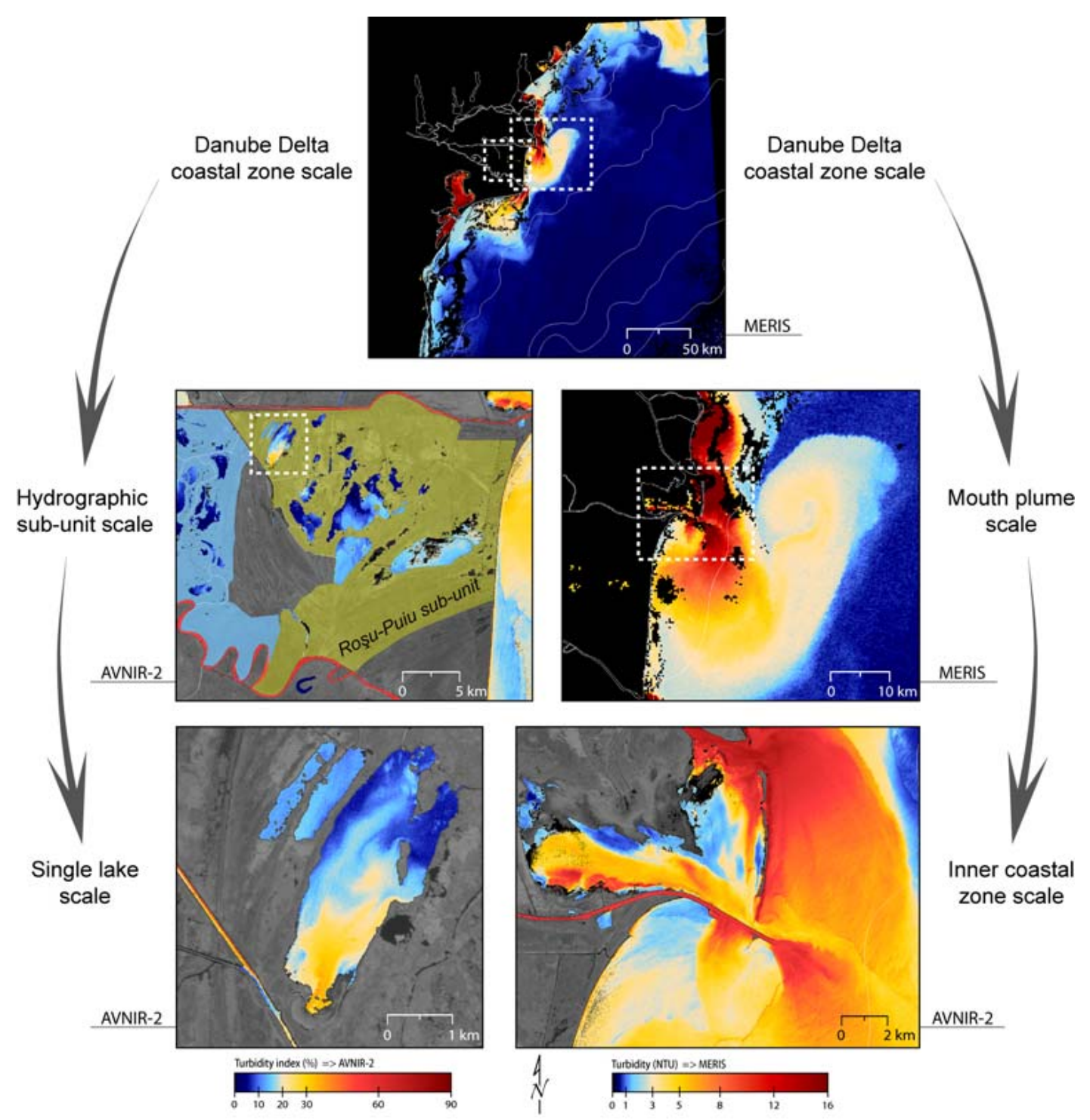

Fig. 11. Integrated view and reciprocal contributions between medium and high spatial resolution turbidity products. The satellite images (MERIS and AVNIR-2) were acquired on 21th July 2009.

In brief, turbidity spatial patterns in the coastal zone could be satisfactorily explained by the interaction of hydrological (principally solid and liquid river discharges) and meteorological (principally wind direction and speed) factors. In the delta plain lakes, phytoplankton growth seems to play a very important role to explain turbidity variability in several lakes. Besides, river direct influence on turbidity is more effective during winter and appears to be restricted to some lakes (connected to turbid inflow points or exposed to overflow events) during the other seasons. The maintenance of lake's clear waters since spring until late summer is likely to be indirectly supported by high river water levels. Two principal processes could be announced. First, the hydrographic sub-units are rapidly filled up when the Danube water level rises in the beginning of spring. Following this short "filling-up" phase, even if the water levels remain high, the turbidity input through the inflow points decrease and sometimes cease. This water "saturation" (together with macrophytes "filtration" effect) inside the hydrographic sub-units prevents or reduces considerably the turbidity inputs all along the duration of steady high water levels. Second, steady high water levels are likely to have an important negative impact on phytoplankton development during summer (flushing, inflow of reed water and other mechanisms). Lake position (e.g. surrounded by reedbeds) and its hydrological situation (e.g. with a high water replacement factor) can enhance this negative impact on phytoplankton development. 
The exceptionally complex spatial patterns observed for turbidity, associated to an equally important temporal variability of these patterns, claim to a lot of prudence for interpreting punctual field data related to the Danube Delta lakes and coastal zone. Without spatial information (i.e. turbidity and phytoplankton gradients), punctual measurements could be hardly generalized to an entire lake and even less to a hydrographic sub-unit or coastal zone. Therefore, water quality punctual measurements realized repeatedly in those zones (i.e. for monitoring purposes) should integrate a spatial component to be really faithful. The satellite derived products and results presented here may contribute to enhance the pertinence of sampling strategies in the Danube Delta waters.

This work presents new results for the characterization of the Danube Delta waters and explores multisensor turbidity algorithms that can be easily adapted. IFREMER algorithms are able to process either SeaWiFS or MODIS data and will be able to process upcoming Sentinel-3 ocean color data. Turbidity index algorithm can also be performed on data from similar optical sensors available today (i.e. Resourcesat-1 and 2) or on data from upcoming satellites (i.e. Sentinel-2, LDCM). In that light, previous and future periods should be studied in order to improve the description of the patterns discussed here and to provide information on long-term variability and spatial dynamics of the Danube Delta waters. The integrated approach exposed here has the potential for broader application in other deltaic areas, particularly in regions that experience seasonal water level fluctuations and highly variable turbidity spatial patterns.

\section{Acknowledgments}

The authors want to thank Yannick Lageat (Université de Bretagne Occidentale) for supporting this research with valuable recommendations and useful suggestions. We thank Ion Grigoraş (Danube Delta National Institute) for providing valuable advices, technical assistance and Danube water levels data series. We thank also the Danube Delta Biosphere Reserve Authority and the Danube Delta National Institute (in particular Diana Bota) for the assistance during the field campaigns. The satellite images (MERIS, AVNIR-2 and HRVIR) were provided by the European Space Agency through the research project "ALOS/ADEN - Diachronic study on Land cover/Land use in the Danube Delta". All the other satellite images (TM and ETM+) were kindly provided by USGS Earth Resources Observation and Science Center. We thank the National Institute for Marine Research and Development "Grigore Antipa" for providing oceanographic data from the Black Sea as well as the International Commission for the Protection of the Danube River for providing SPM data for the delta branches. We thank João Souza (University of Hawaii) for his attentive comments on the manuscript. We would like to thank also all five anonymous Referees for their helpful comments and suggestions.

\section{References}

Anderson, C.W. (2005). Turbidity (version 2.1). U.S. Geological Survey Techniques of WaterResources Investigations: USGS

ASTM-International (2003). D1889-00 Standard test method for turbidity of water. In A. International (Ed.), Annual Book of ASTM Standards, Water and Environmental Technology. Pennsylvania: West Conshohocken

Bondar, C., \& Panin, N. (2001). The Danube Delta hydrologic database and modelling. Geo-EcoMarina, 5-6, 5-52

Coops, H., Buijse, L.L., Buijse, A.D., Constantinescu, A., Covaliov, S., Hanganu, J., Ibelings, B.W., Menting, G., Navodaru, I., Oosterberg, W., Staras, M., \& Török, L. (2008). Trophic gradients in a largeriver Delta: ecological structure determined by connectivity gradients in the Danube Delta (Romania).

River Research and Applications, 24, 698-709 
Coops, H., Hanganu, J., Tudor, M., \& Oosterberg, W. (1999). Classification of Danube Delta lakes based on aquatic vegetation and turbidity. Hydrobiologia, 415, 187-191

Cristofor, S., Vadineanu, A., Sarbu, A., Postolache, C., Dobre, R., \& Adamescu, M. (2003). Long-term changes of submerged macrophytes in the Lower Danube Wetland System. Hydrobiologia, 506-509, 625-634

Dan, S., Stive, M.J.F., Walstra, D.-J.R., \& Panin, N. (2009). Wave climate, coastal sediment budget and shoreline changes for the Danube Delta. Marine Geology, 262, 39-49

Davies-Colley, R.J., \& Smith, D.G. (2001). Turbidity, suspended sediment and water clarity: a review. JAWRA Journal of the American Water Resources Association, 37, 1085-1101

Dinu, I., Bajo, M., Umgiesser, G., \& Stanica, A. (2011). Influence of wind and freshwater on the current circulation along the Romanian Black Sea coast. Geo-Eco-Marina, 17, 13-26

Doxaran, D., Froidefond, J.-M., Castaing, P., \& Babin, M. (2009). Dynamics of the turbidity maximum zone in a macrotidal estuary (the Gironde, France): Observations from field and MODIS satellite data. Estuarine, Coastal and Shelf Science, 81, 321-332

Doxaran, D., Froidefond, J.-M., Lavender, S., \& Castaing, P. (2002). Spectral signature of highly turbid waters: Application with SPOT data to quantify suspended particulate matter concentrations. Remote Sensing of Environment, 81, 149-161

Driga, B.-D. (2004). Delta Dunarii - Sistemul circulatiei apei. Cluj-Napoca: Casa Cartii de Stiinta

Ferrari, G.M., Hoepffner, N., \& Mingazzini, M. (1996). Optical properties of the water in a deltaic environment: Prospective tool to analyze satellite data in turbid waters. Remote Sensing of Environment, 58, 69-80

Forster, B.C., Xingwei, S.H.A., \& Baide, X.U. (1993). Remote sensing of sea water quality parameters using Landsat-TM. International Journal of Remote Sensing, 14, 2759-2771

Froidefond, J.-M., Castaing, P., Mirmand, M., \& Ruch, P. (1991). Analysis of the turbid plume of the Gironde (France) based on SPOT radiometric data. Remote Sensing of Environment, 36, 149-163

Froidefond, J.-M., \& Doxaran, D. (2004). Télédétection optique appliquée à l'étude des eaux côtières. Télédétection, 4, 579-597

Froidefond, J.M., Lahet, F., Hu, C., Doxaran, D., Guiral, D., Prost, M.T., \& Ternon, J.F. (2004). Mudflats and mud suspension observed from satellite data in French Guiana. Marine Geology, 208, 153-168

Gâştescu, P., \& Stiuca, R. (Eds.) (2008). Delta Dunării : Rezervaţie a Biosferei. Bucharest: CD PRESS

Giosan, L. (2007). Morphodynamic feedbacks on deltaic coasts: Lessons from the wave-dominated Danube delta. Coastal Sediments, 'O7

Gohin, F. (2011). Annual cycles of chlorophyll-a, non-algal suspended particulate matter, and turbidity observed from space and in-situ in coastal waters. Ocean Sci., 7, 705-732

Gohin, F., Druon, J.N., \& Lampert, L. (2002). A five channel chlorophyll concentration algorithm applied to SeaWiFS data processed by SeaDAS in coastal waters. International Journal of Remote Sensing, 23, 1639-1661

Gohin, F., Loyer, S., Lunven, M., Labry, C., Froidefond, J.-M., Delmas, D., Huret, M., \& Herbland, A. (2005). Satellite-derived parameters for biological modelling in coastal waters: Illustration over the eastern continental shelf of the Bay of Biscay. Remote Sensing of Environment, 95, 29-46

Hadjimitsis, D.G., Clayton, C.R.I., \& Retalis, A. (2009). The use of selected pseudo-invariant targets for the application of atmospheric correction in multi-temporal studies using satellite remotely sensed imagery. International Journal of Applied Earth Observation and Geoinformation, 11, 192-200

Hanganu, J., Grigoras, I., Stefan, N., Sarbu, I., Dubdyna, D., Zhmud, E., Menke, U., \& Drost, H. (2002). Vegetation of the Biosphere Reserve "Danube Delta". In (p. 88): Institute for Inland Water Management and Waste Water Treatment (RIZA) 
Harrington Jr, J.A., Schiebe, F.R., \& Nix, J.F. (1992). Remote sensing of Lake Chicot, Arkansas: Monitoring suspended sediments, turbidity, and Secchi depth with Landsat MSS data. Remote Sensing of Environment, 39, 15-27

Karageorgis, A., Kourafalou, V., Anagnostou, C., Tsiaras, K., Raitsos, D., Papadopoulos, V., \& Papadopoulos, A. (2009). River-induced particle distribution in the northwestern Black Sea (September 2002 and 2004). Journal of Geophysical Research, 114, C12003

Lathrop, R.G., \& Lillesand, T.M. (1986). Use of Thematic Mapper data to assess water quality in Green Bay and central Lake Michigan. Photogrammetric Engineering and Remote Sensing, 52, 671-680

Lathrop, R.G.J., \& Lillesand, T.M. (1989). Monitoring water quality and river plume transport in Green Bay, Lake Michigan with SPOT-1 imagery. Photogrammetric Engineering and Remote Sensing, 55, 349-354

Ludwig, W., Dumont, E., Meybeck, M., \& Heussner, S. (2009). River discharges of water and nutrients to the Mediterranean and Black Sea: Major drivers for ecosystem changes during past and future decades? Progress In Oceanography, 80, 199-217

Mikhailov, V., \& Mikhailova, M. (2008). River Mouths. In A. Kostianoy \& A. Kosarev (Eds.), The Black Sea Environment (pp. 91-133): Springer Berlin / Heidelberg

Novo, E.M.M., Hansom, J.D., \& Curran, P.J. (1989). The effect of viewing geometry and wavelength on the relationship between reflectance and suspended sediment concentration. International Journal of Remote Sensing, 10, 1357-1372

NWEA, N.W.E.A.-. (2000). Laboratory Practices Manual for Waste Water Treatement Facilities: Nebraska Water Environment Association

Onderka, M., \& Pekárová, P. (2008). Retrieval of suspended particulate matter concentrations in the Danube River from Landsat ETM data. Science of The Total Environment, 397, 238-243

Onderka, M., \& Rodný, M. (2010). Can suspended sediment concentrations be estimated from multispectral imagery using only image-derived information? Journal of the Indian Society of Remote Sensing, 38, 85-97

Oosterberg, W., Buijse, A.D., Coops, H., Ibelings, B.W., \& Menting, G.A.M. (2000). Ecological gradients in the Danube delta lakes: present state and man-induced changes: RIZA the Netherlands, Danube Delta National Institute Romania and Danube Delta Biosphere Reserve Authority

Pattiaratchi, C., Lavery, P., Wyllie, A., \& Hick, P. (1994). Estimates of water quality in coastal waters using multi-date Landsat Thematic Mapper data. International Journal of Remote Sensing, 15, 1571 1584

Petus, C., Chust, G., Gohin, F., Doxaran, D., Froidefond, J.-M., \& Sagarminaga, Y. (2010). Estimating turbidity and total suspended matter in the Adour River plume (South Bay of Biscay) using MODIS 250m imagery. Continental Shelf Research, 30, 379-392

Ragueneau, O., Lancelot, C., Egorov, V., Vervlimmeren, J., Cociasu, A., Déliat, G., Krastev, A., Daoud, N., Rousseau, V., Popovitchev, V., Brion, N., Popa, L., \& Cauwet, G. (2002). Biogeochemical Transformations of Inorganic Nutrients in the Mixing Zone between the Danube River and the Northwestern Black Sea. Estuarine, Coastal and Shelf Science, 54, 321-336

Schott, J.R., Salvaggio, C., \& Volchok, W.J. (1988). Radiometric scene normalization using pseudoinvariant features. Remote Sensing of Environment, 26, 1-16

Tassan, S. (1993). An improved in-water algorithm for the determination of chlorophyll and suspended sediment concentration from Thematic Mapper data in coastal waters. International Journal of Remote Sensing, 14, 1221-1229

Tolmazin, D. (1985). Changing Coastal oceanography of the Black Sea. I: Northwestern Shelf. Progress In Oceanography, 15, 217-276

Tudorancea, C., \& Tudorancea, M. (2006). Danube Delta : Genesis and Biodiversity. Leiden: Backhuys Publishers

Vadineanu, A., Cristofor, S., \& Ignat, G. (1992). Phytoplankton and submerged macrophytes in the aquatic ecosystems of the Danube Delta during the last decade. Hydrobiologia, 243-244, 141-146 